\title{
scripted
}

Volume 17, Issue 1, January 2020

\section{The Allocation of Patent Ownership in R\&D Partnerships: Default Rules v. Contractual Practices}

\author{
Arina Gorbatyuk* \\ (ㄷ) (1) $(9)$ \\ (C) 2020 Arina Gorbatyuk \\ Licenced under a Creative Commons Attribution-NonCommercial- \\ NoDerivatives 4.0 International (CC BY-NC-ND 4.0) licence
}

DOI: $10.2966 /$ scrip.170120.4

\begin{abstract}
Due to the increased complexity of new technologies and rapid technological developments, organisations often cannot independently keep up with the technological progress and engage in open innovation activities by setting up R\&D partnerships. The allocation of patent ownership of jointly developed inventions is a difficult issue during the negotiations of such partnerships and can be extremely problematic due to the lack of regulation and harmonisation of patent legislation. This entails the need to consult a considerable number of legal systems that may be involved in large-scale international partnerships. The difficulties in allocating ownership can also arise due to non-legal reasons, such as diverging business interests. While many patent systems suggest coownership as a default regime, in practice organisations often avoid it due to the complexity related to further joint exploitation. The principle of freedom of contract allows organisations to establish their own applicable rules governing the allocation of ownership and exploitation of jointly developed inventions. Those rules provide more flexibility, but also imply some transaction costs in designing contracts. In this paper I examine why
\end{abstract}


certain default rules are not "sticky" and whether it would be possible to establish a default rule accepted by the majority of the negotiating parties.

\section{Keywords}

Patent ownership, co-ownership, R\&D collaboration, open innovation, default rules, contractual freedom

* Postdoctoral Researcher; the Center for IT \& IP Law (CiTiP), KU Leuven and the Research Group Government \& Law, UAntwerp, Belgium, arina.gorbatyuk@kuleuven.be. 


\section{Introduction}

Due to the technological advances and the increased complexity of new technologies, engagement in open innovation (OI) activities has become gradually common. In particular, various organisations increasingly engage in coupled OI activities by establishing diverse types of R\&D partnerships. ${ }^{1}$ Those R\&D partnerships may be complicated, both from legal and managerial perspectives, and tend to involve many partners. These partners generally come from different legal systems and from both private and public sectors. The economic and managerial literature exhaustively examines the benefits and risks of engagement in those partnerships and explores motivations of partners for cocreation. $^{2}$

In setting up an R\&D partnership, one of the aims is to jointly conduct an $R \& D$ process. OI is mainly focused on technological innovation and, thus, the outcomes of an R\&D process will generally be technological inventions. Parties may safeguard generated inventions by means of intellectual property (IP) protection, in particular patent protection.

Various stakeholders from different sectors highlighted the allocation of IP ownership as a major challenge in an OI context. ${ }^{3}$ The complexity of the allocation of ownership of jointly developed inventions is illustrated in Figure 1. A US multinational pharmaceutical company (A) and a French medium-size medical equipment company (B) established an international R\&D partnership

1 Bruce Tether, "Who Co-operates for Innovation, and Why: An Empirical Analysis" (2002) 31(6) Research Policy 947-963, p. 947; John Hagedoorn, "Inter-firm R\&D Partnerships: An Overview of Major Trends and Patterns since 1960" (2002) 31(4) Research Policy 477-492, p. 480; Martin Bader, Intellectual Property Management in RED Collaborations (Heidelberg: PhysicaVerlag, 2006), p. 5; Arina Gorbatyuk, Geertrui Van Overwalle and Esther van Zimmeren, "Intellectual Property Ownership in Coupled Open Innovation Processes" (2016) 47(3) International Review of Intellectual Property and Competition Law 262-302, p. 288.

2 Tether, supra n. 1, p. 947; Luis Miotti and Frédérique Sachwald, "Co-operative R\&D: Why and with Whom?: An Integrated Framework of Analysis" (2003) 32(8) Research Policy 1481-1499.

3 Interviews conducted in the framework of this research. 
to jointly carry out R\&D. However, due to the intricate nature of knowledge cocreation, it may be unclear which particular rights each collaborating party has towards the jointly developed inventions. The following questions could arise in such a situation: (1) Do A and B automatically co-own patent protected jointly developed inventions or can one of the two be the sole owner? (2) Can A and B independently exploit the jointly developed inventions? In particular, can B assign its patent rights to a French pharmaceutical company $(\mathrm{C})$ without the consent of A? Similarly, can A give a non-exclusive licence to a Belgian private research institute (D) or an exclusive licence to a German multinational medical equipment company (E) without the consent of B? ${ }^{4}$

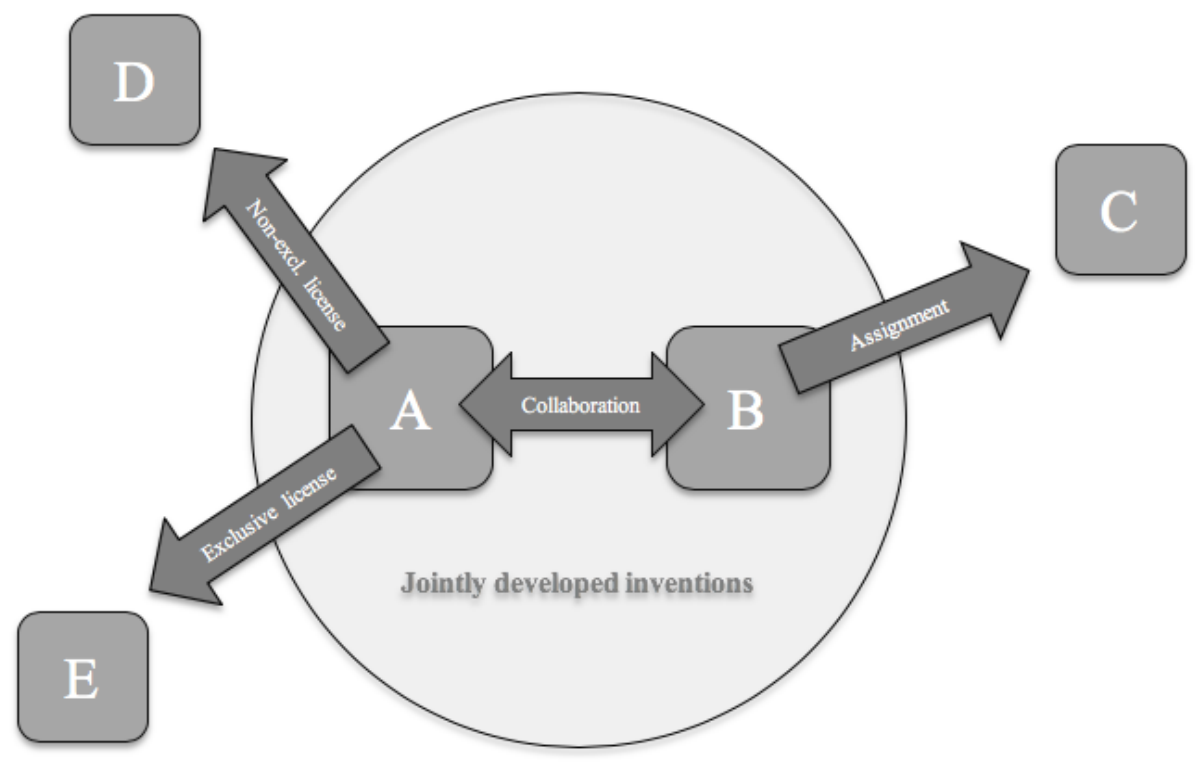

Figure 1: Practical aspects of the allocation of ownership of jointly developed inventions

In patent law, many legal systems impose co-ownership as the default regime for jointly developed technologies. Default rules, in legal theory, are rules of law that

4 The example was originally provided in Gorbatyuk, Van Overwalle and van Zimmeren, supra n. 1, p. 265. 
can be modified by an agreement between the parties. ${ }^{5}$ Those rules are opposite to mandatory rules, which are to be enforced even if parties decide to modify them through a contract. ${ }^{6}$ The advantage of the default rules regarding coownership is that they pay respect to the intellectual efforts of all inventors involved and safeguard a fair distribution of ownership. ${ }^{7}$ The general aim of default rules is to provide contracting parties with basic rules which make it easier and less costly for parties to regulate their collaboration. ${ }^{8}$ However, the application of default rules may lead to legal uncertainty and high coordination costs in international R\&D partnerships, as legal provisions vary, and several legal systems prescribe the consultation and consent of co-owners in case of use, licencing, and sale of co-owned patents. Those differences in legislation may create uncertainty depending on the applicable law and may complicate or substantially delay future exploitation of technology. Moreover, the consent requirement may harm the interests of collaborating parties and limit their freedom in the exploitation of jointly developed technologies, which in turn may discourage engagement in further OI activities.

To avoid the complexity created by the variety of applicable legal provisions, parties can contract out of the default regime and establish their own rules applicable for their partnership. Stakeholders can use the possibility to establish a contract-based regime, guaranteed by the principle of freedom of

5 Ian Ayres and Robert Gertner, "Filling Gaps in Incomplete Contracts: An Economic Theory of Default Rules" (1989) 99(1) Yale Law Journal 87-130, p. 87.

6 Ibid. Mandatory rules which may limit contractual freedom of parties establishing R\&D partnerships, e.g. mandatory rules of labour law and competition law, are outside the scope of this article. They are, however, analysed in detail in my $\mathrm{PhD}$ (see infra n. 103). See also infra n. 97.

7 They are so-called "normative defaults", see Alan Schwartz, "The Default Rule Paradigm and the Limits of Contract Law" (1993) 3(1) Southern California Interdisciplinary Law Journal 389-420, p. 391.

8 Martijn W Hesselink, “Non-Mandatory Rules in European Contract Law” (2005) 1(1) European Review of Contract Law 44-86, p. 46. 
contract. This regime provides more flexibility, but also implies some contracting costs in designing a contract.

The general aim of this paper is to review whether organisations follow the existing default rules in practice and under which circumstances. In other words, the goal is to assess whether the existing default rules are "sticky". 9 Furthermore, it is analysed whether there are other useful mechanisms that could be installed to decrease contracting costs of negotiating the allocation of patent ownership.

In order to achieve the identified goal, the paper answers the following three main research questions (RQ):

RQ1: How is patent ownership of jointly developed inventions allocated according to the legislator of the United States of America (US), France, Belgium, and Germany?

RQ2: How is patent ownership of jointly developed inventions allocated in practice?

RQ3: How "sticky" are the existing default rules? Is there room for improvement?

Each section of this article is dedicated to one of the research questions. In particular, in Section 2 the default rules on the allocation of patent ownership of jointly developed inventions and exploitation rights of co-owned patents are reviewed. The paper incorporates an analysis of four jurisdictions, the US, France, Belgium, and Germany. Those jurisdictions were selected since their default rules vary and provide a different perspective on existing default rules.

\footnotetext{
9 The default rules are "sticky" if parties follow them and do not have the need to contractually modify them. If default rules are "sticky" it means that the legislator provided the default which the majority of the parties prefer (a so-called "majoritarian" default rule). For more information see Section 4 of this paper.
} 
To date, the legal scholarship on patent co-ownership is limited and consists of several papers focusing on one or two jurisdictions. ${ }^{10}$

In Section 3 the contractual practices of the allocation of patent ownership of jointly developed inventions are analysed. The analysis is based on empirical data obtained through 56 semi-structured interviews conducted with representatives of various organisations, e.g. multinational enterprises (MNEs), small and medium-sized enterprises (SMEs), technology transfer offices (TTOs), and research institutions (RIs). Interviewed representatives work for organisations from various industry sectors and are based in different countries. ${ }^{11}$ Each representative was asked a set of 25 questions. ${ }^{12}$ The majority of the interviews (54/56) were recorded and transcribed later on; the remaining two interviews were drafted during the conversation. The interviews were analysed and coded through NVivo software. ${ }^{13}$ The obtained data permitted to learn about the contractual practices established by organisations when negotiating R\&D partnerships and the underlying motivation for opting for certain contractual clauses dealing with patent ownership. To my knowledge, no empirical analysis

10 E.g. Robert Merges and Lawrence Locke, "Co-ownership of Patents: A Comparative and Economic View" (1990) 72(6) Journal of the Patent and Trademark Office Society 586-599; David Marchese, "Joint Ownership of Intellectual Property" (1999) 21(7) European Intellectual Property Review 364-366; Robert Paradiso and Elizabeth Pietrowski, "Dilemmas of Joint Patent Ownership" (2009) 197 New Jersey Law Journal 912-913; Bruce Banks et al., "Dealing with Joint Intellectual Property Ownership in the US and Germany" (2011) 36 DAJV Newsletter 58-63.

11 See Annex I for the overview. The majority of interviews are taken with multinational MNEs. Even though the majority of interviews took place in Belgium, the contractual practices shared by the representatives often correspond to the global approach of the company, rather than of a particular local branch. Moreover, it was observed that even though the law may differ in various jurisdictions, the contractual preferences of MNEs do not differ much depending on the jurisdiction.

12 The questionnaire used during the interviews is divided into three sections: (1) general information about R\&D partnerships (types of agreements and partners, modes of funding applied); (2) IP issues in R\&D partnerships (preferred modes of protection; allocation of background IP and foreground IP); (3) other relevant contractual provisions (applicable law; jurisdiction). In this article I focus on the questions related to the allocation of foreground IP (infra n. 22).

13 https://www.qsrinternational.com/nvivo/nvivo-products (accessed 26 July 2019). 
on the allocation of patent ownership in R\&D partnerships has been conducted by legal scholars.

In Section 4 the interface between existing default rules and contractual practices is analysed. In particular, I analyse whether the existing default rules are "sticky". In other words, it is observed whether parties are satisfied with the suggested default rules or they prefer to contractually establish the rules applicable to their relationship. In this Section I aim to contribute to the legal scholarship on default rules. The existing legal literature focuses, first, on the general theory on default rules, which is often linked to behavioural sciences. ${ }^{14}$ Second, the literature focuses on statutory default rules in contract law, which can also be connected to other fields of law, e.g. corporate law, commercial law, and employment law. ${ }^{15}$ Default rules in contract law and other fields of the law are closely related: default rules (regardless of which field of the law they belong to) determine contractual obligations between the parties, unless the parties do not specifically override them in their contracts. To my knowledge, default rules of IP law have not been analysed yet in detail and in a systematic way.

It is concluded that existing default rules are not "sticky" since they do not satisfy the interests of parties engaging in $R \& D$ partnerships due to their complexity and unharmonised nature. Contractual parties are willing to increase

14 Cass Sunstein, Choosing not to Choose: Understanding the Value of Choice (Oxford: OUP, 2015); Cass Sunstein, "Opinion: Default Rules Are Better Than Active Choosing (Often)" (2017) 21(8) Trends in Cognitive Sciences 600-606.

15 Ayres and Gertner, supra n. 5; James White, "Default Rules in Sales and the Myth of Contracting Out" (2002) 48(1) Loyola Law Review 53-86; Cass Sunstein, "Switching the Default Rule" (2002) 77(1) New York University Law Review 106-134; Alan Schwartz and Robert E Scott, "Contract Theory and the Limits of Contract Law" (2003) 113(3) Yale Law Journal 541-619; Hesselink, supra n. 8; Omri Ben-Shahar and John Pottow, "On the Stickiness of Default Rules" (2006) 33(3) Florida State University Law Review 651-682; Brett McDonnell, "Sticky Defaults and Altering Rules in Corporate Law" (2007) 60 SMU Law Review 383-439; Matthias Storme, "Freedom of Contract: Mandatory and Non-Mandatory Rules in European Contract Law" (2007) 15 European Review of Private Law 233-250; Ian Ayres, "Regulating Opt-Out: An Economic Theory of Altering Rules" (2012) 121(8) Yale Law Journal 2032-2116. In this paper only the literature that focuses on statutory default rules in contract law is reviewed. 
the transaction costs of contract negotiations, rather than risk legal uncertainly created by existing default rules. The logical follow-up question that arises is whether legislators might provide a default rule which would be accepted by the majority of organisations ("a majoritarian default rule"16).

\section{Default rules on the allocation of ownership of jointly developed inventions and exploitation rights}

Prior to any joint R\&D activity, it is common for collaborating parties to negotiate an underlying agreement that governs the R\&D partnership. From a legal perspective, R\&D partnerships can be established through conducting four types of agreements: R\&D contract research agreements, ${ }^{17}$ R\&D collaboration agreements, $^{18}$ R\&D consortium agreements, ${ }^{19}$ and $R \& D$ joint venture agreements. ${ }^{20,21}$ Regardless of the type of agreement at stake, the allocation of ownership of jointly developed knowledge, or so-called "foreground $\mathrm{IP}^{\prime}, 22$ is generally one of the important negotiation points.

Default rules are applicable when collaborating parties do not contractually establish rules that deviate from the ones suggested by the

16 Ian Ayres and Robert Gertner, “Majoritarian vs. Minoritarian Defaults" (1999) 51(6) Stanford Law Review 1591-1613.

17 R\&D contract research agreements are contractual arrangements involving an external specialist who will conduct the R\&D process and receive financial remuneration for it.

$18 R \& D$ collaboration agreements are agreements that involve several partners, working jointly on a particular research project.

19 R\&D consortium agreements are project management and collaboration agreements for a large consortium of partners, which often come from private and public sectors and join forces to solve a complex problem in a particular field of research.

20 R\&D joint venture agreements are agreements under which several parties, remaining independent, form a separate new joint undertaking. This agreement is not addressed in this paper.

21 For more detailed information consult Gorbatyuk, Van Overwalle and van Zimmeren, supra n. 1, p. 288. The actual naming of the agreements can vary in practice.

22 Foreground IP consists of IP-protected knowledge which is generated by collaborating parties within the framework of the R\&D partnership. 
legislator. ${ }^{23}$ It may happen that collaborating parties do not have a contract that governs their R\&D activity at all or that the contract they negotiated does not address the issue of allocation of ownership of foreground IP or cover all the important aspects. ${ }^{24}$ For instance, if $\mathrm{A}$ and $\mathrm{B}^{25}$ do not specify how the right to apply for a patent should be allocated, the default rules suggested in patent law are applicable. Similarly, if they do not contractually specify how the co-owned patent should be exploited, the exploitation rights provided in patent law should be followed. However, even if A and B originally failed to contract out of the default rules, they can contractually establish the preferred rules at any moment, even after the grant of the patent. Nevertheless, it is considered that negotiating applicable rules after inventions are developed is more problematic since the R\&D outcome materialises and both parties may see the immediate (financial) gain.

\subsection{Default rules on the allocation of ownership of jointly developed inventions}

Prior to analysing specific default rules related to the allocation of ownership of jointly developed inventions, I briefly describe the stages that an organisation needs to go through to become an owner of a patent. ${ }^{26}$

23 See Section 4.

24 For instance, collaborating parties may contractually specify how the ownership should be divided but do not address how the co-owned patent should be exploited.

25 Figure 1.

26 Figure 2. 

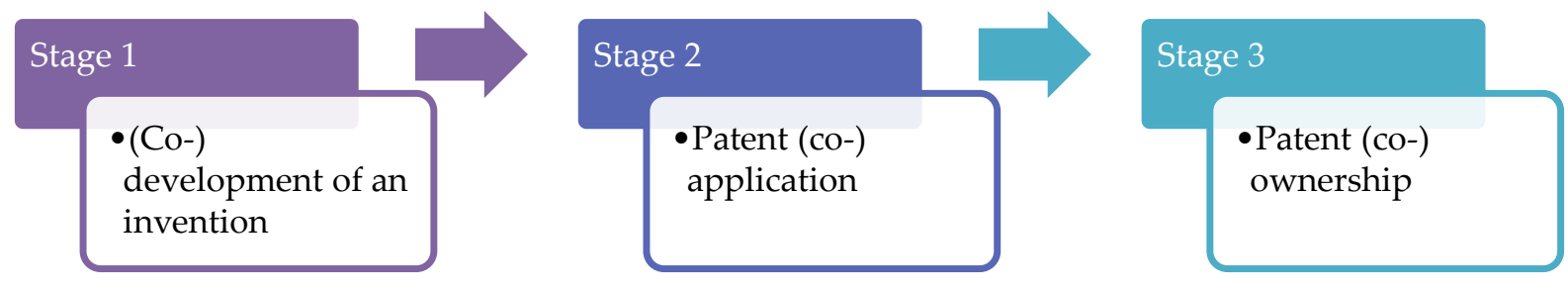

Figure 2: From (co-)inventorship to (co-)ownership

Stage 1: (co-)development of an invention: first of all, an inventor develops an invention which is potentially suitable for patent protection. ${ }^{27}$ Once an invention is created, the inventor obtains a kind of "right to an invention". ${ }^{28}$ This right is linked to the concept of inventorship and cannot be transferred to anyone else. It can be shared with other co-inventors, in case more than one inventor developed the invention.

Stage 2: (co-)patent application: since the original right to apply for a patent is vested with its inventor, he has the right to apply for a patent. ${ }^{29}$ This right is, however, assignable and in employee-employer relationships an employee is often under a contractual or legal obligation to assign it to his employer. ${ }^{30}$ Consequently, the employer (organisation) will obtain the right to apply for a patent by way of an assignment. In spite of that assignment, an inventor has the right to be mentioned as an inventor on the patent application, as inventorship is not assignable. ${ }^{31}$ Organisations can apply for a patent jointly. ${ }^{32}$ According to the default regime, whether a joint application is possible will

27 European Patent Convention 1973 (EPC), art. 52.

28 Alexander R Klett, Matthias Sonntag and Stephan Wilske, Intellectual Property Law in Germany: Protection, Enforcement and Dispute Resolution (Munich: C.H. Beck, 2008), p. 7; Christopher McDavid, "I Want a Piece of That - How the Current Joint Inventorship Laws Deal with Minor Contributions to Inventions" (2010) 115 Penn State Law Review 449-471, p. 450.

29 EPC, art. 60; US Code Title 35, art. 111 (35 U.S.C. 111).

30 McDavid, supra n. 28, p. 455. Depending on the jurisdiction, however, employees may be entitled to compensation for their inventions, infra n. 97.

31 Paris Convention for the Protection of Industrial Property 1883, art. 4ter; EPC, art. 62; 35 U.S.C. 115(a).

32 EPC, art. 59; 35 U.S.C. 116(a). 
generally depend on whether employees from those organisations concerned were actually involved in the development of the invention.

Stage 3: patent (co-)ownership: in case the patent is granted, the patent applicant becomes the owner of a patent. ${ }^{33}$ If several organisations applied for a patent jointly, they will become co-owners of a patent.

Thus, the main aspect that has to be taken into consideration, when allocating ownership following the default regime, is whether the invention developed in the framework of an R\&D partnership was developed jointly by inventors employed by both collaborating organisations. In other words, at least one employee of A and one employee of B should have contributed to the invention. Consequently, if employees of both companies contributed to the invention, through an assignment of the right to apply for a patent from an employee to an employer, both companies would have the right to apply for a patent as co-applicants. ${ }^{34}$ In case of successful patent prosecution, A and B will be co-owners.

\subsection{Default rules on the exploitation of co-owned patents}

Patents confer on their owners the exclusive rights to prevent third parties from exploiting the patented invention without having the owners' consent. ${ }^{35}$ Patent owners also have the right to use a patent, the right to grant a licence, and the right to assign a patent. ${ }^{36}$ Those rights form so-called patent exploitation rights. ${ }^{37}$ The sole owner of a patent exercises those rights independently. Administration of co-owned patents and exploitation of co-owned patent rights are more

33 There are also other possibilities to become a patent owner, e.g. through an assignment agreement, inheritance or bankruptcy.

34 EPC, art. 59; 35 U.S.C. 116.

35 TRIPS, art. 28(1).

36 TRIPS, art. 28(2).

37 Patent owners also have the right to enforce their patent. The issue of enforcement is not addressed in this article. 
complicated. The obtained patent is generally treated as a common property ${ }^{38}$ and each co-owner obtains an equal undivided partial interest in the entire patent ${ }^{39}$. Thus, all co-owners obtain equal rights and obligations. ${ }^{40}$

Despite the fact that co-owners have identical rights, depending on the jurisdiction they may not be permitted to exploit them independently. ${ }^{41}$ In particular, a co-owner may be required to obtain the consent from other coowners to exploit his rights to use, licence or assign the co-owned patent. On the one hand, the consent requirement ensures that all patent co-owners are involved in patent exploitation strategies. On the other hand, such close cooperation may negatively affect patent exploitation strategies of a co-owner who is interested in engaging in OI activities when other co-owners take a more traditional, "closed" approach and prevent the OI minded owner from granting a licence.

Patent law generally contain specialised rules governing co-owned patents and their exploitation. Those rules differ from rules of civil law, and often it is acknowledged explicitly that the intangible nature of patents requires a special approach towards co-ownership, which differs from tangible co-owned

38 Some legal scholars refer to co-owned patents as "tenancy in common". Anthony William Deller, Walker on Patents, vol. 2 (New York: Baker, Voorhis and Company, 1937), p. 1449; Harrington Lackey, "Problems in Joint Ownership of Patents" (1958) 11(3) Vanderbilt Law Review 697-736, p. 710; Merges and Locke, supra n. 10, p. 587; Sheldon Halpern, Sean Seymore, and Kenneth Port, Fundamentals of United States Intellectual Property Law: Copyright, Patent, Trademark (Alphen aan den Rijn: Wolters Kluwer, 2015), p. 222.

39 Co-ownership regime is applied for the entire patent; the ownership regime does not differ per claim. Regardless of individual contributions of each co-owner, each co-owner is entitled to exclusivity for the whole invention. Co-owners may contractually allocate their shares of the patent unequally, for instance, based on the contributions to patent claims. It could be important to contractually specify the exact shares since it may affect the allocation of amount of revenues or damages for patent rights infringement. Deller, supra n. 38, p. 406; Lackey, supra n. 38, p. 711; Merges and Locke, supra n. 10, p. 587; Joachim Feldges and Birgit Kramer, "Coownership of Patents under German Law" (2007) 2(11) Journal of Intellectual Property Law \& Practice 742-749, p. 746; Maximilian Haedicke and Henrik Timmann, Patent Law: A Handbook on European and German Patent Law (Munich: C.H. Beck, 2014), p. 261; Paradiso and Pietrowski, supra n. 10, p. 197; Banks, supra n. 10, p. 58-59.

40 In practice co-owners may in some cases contractually agree otherwise. For instance, they may contractually limit their exploitation rights.

41 See Table 1 for the overview. 
goods. ${ }^{42}$ In particular, patent laws of the US, ${ }^{43}$ France, and Belgium contain such specialised patent co-ownership rules. However, not all countries have such specialised rules. For instance, in Germany rules related to co-ownership are governed by civil law. ${ }^{44}$

\subsubsection{US default rules on the exploitation of co-owned patents}

According to 35 U.S.C. 262 each of the co-owners of a patent "may make, use, offer to sell, or sell the patented invention within the United States... without the consent of and without accounting to the other owners". This provision indicates that each co-owner does not have to acquire the consent from other co-owners or notify them of any type of exploitation activities, e.g. use, ${ }^{45}$ licencing $^{46}$ or

42 For instance, according to L613-30 of the Intellectual Property Code of France 2014 (CPI) provisions on co-ownership specified in civil law are not applicable. Art. XI.49 of the Belgian Code of Economic Law 2013 (CEL) also contains a similar provision.

43 It must be noted that patents in the US are governed by the US Patent Act (codified in Title 35 of the U.S.C., supra n. 29). The grant and enforcement of patents are exclusively matters of federal jurisdiction. Furthermore, with regard to co-owned patents 35 U.S.C. 262 specifies default rules on their exploitation. However, the ownership of the patent (e.g. the transfer of ownership) is determined under the relevant state law. R\&D partnership agreements, in which collaborating parties can allocate patent ownership and/or deviate from the suggested default rules on the exploitation of co-owned patents, are subject to state contract laws. For more information see Edward H. Cooper, "State Law of Patent Exploitation" (1972) 56 Minnesota Law Review 313-391; Justin Nifong, "Patent ownership" (2013), available at http://nkpatentlaw.com/patent-ownership/ (accessed 26 July 2019).

44 German Civil Code 2002 (BGB), s. 741.

45 In Blacklegde $v$ Weir \& Graig Mfg Co the court specified that "while the statute regulating the subject authorizes the issue of a patent to two or more, and the transfer by assignment of partial interests to different persons, it contains no expression or intimation that one owner may not use the invention without the consent of the co-owner". Blackledge $v$ Weir \& Graig Mfg Co 108 Fed 71 (1901).

46 In Schering Corp v Roussel-UCLAF SA the court stated that "unless the co-owner has given up [its] rights through an 'agreement to the contrary', the co-owner may not be prohibited from exploiting its rights in the patent, including the right to grant licences to third parties on whatever conditions the co-owner chooses". Schering Corp v Roussel-UCLAF SA 104 F 3d 341, 344 (1997). 
assignment, ${ }^{47}$ irrespective of the amount of his interest in the patent. ${ }^{48}$ In comparison to other selected jurisdictions, the U.S.C. adopts the most flexible approach towards exploitation of co-owned patents, giving co-owners freedom to exploit the co-owned patent without the consent and without notification. ${ }^{49}$ Moreover, co-owners are not obliged to share profits generated through exploitation of a co-owned patent with each other. ${ }^{50}$ Contrary to French and Belgian provisions, neither the US legislative provisions nor the case law grant co-owners a right of pre-emption when one of the co-owners decided to sell his share of a patent.

On the one hand, such a high level of freedom has positive aspects. In particular, a co-owner can decide upon his exploitation strategies without being "blocked" by other co-owners. Furthermore, it allows avoiding extra administrative burden, such as an acquisition of consent, which can be very timeconsuming. Not to mention that other co-owners cannot influence the negotiation process of a licencing agreement and "impose" their conditions or prolong it.

47 In Walker on Patents it is stressed that a co-owner may "sell specimens of the patented invention to any extent" (Deller, supra n. 38, p. 1450). However, he cannot assign the full patent to a third party. It is explicitly stated in Pitts $v$ Hall that "neither can transfer or dispose of the whole property; nor can one act for the other in relation thereto, but merely for his own share, and to the extent of his own several right and interest". Pitts v Hall 8 Blatch 201(1854); William C Robinson, The Law of Patents for Useful Inventions, vol. 2 (New York: Little, Brown, and Company, 1890), p. 565.

48 Dwight Cheever, "The Rights of Joint Owners of a Patent" (1904) 2(6) Michigan Law Review Association 446-452, p. 447; Deller, supra n. 38, p. 1450; Ernest Bainbridge Lipscomb III, Walker on Patents, vol. 5 (New York: The Lawyers Co-operative Pulishing Company, 1986), p. 461; Lackey, supra n. 38, p. 711; AIPPI US, "The Impact of Co-Ownership of Intellectual Property Rights on their Exploitation" (2007), p. 3, available at https://www.aippi.org/download/commitees/194/GR194usa.pdf (accessed 26 July 2019); McDavid, supra n. 28, p. 454; Lim Heng Gee, "The Default Rules Relating To Joint Ownership of Patents -Pitfalls for the Unwary" (2014) 22 Pertanika Journal of Social Sciences \& Humanities 45-64, p. 49; Banks, supra n. 10, p. 59.

49 Gorbatyuk, Van Overwalle and van Zimmeren, supra n. 1, p. 276.

50 In Blackledge $v$ Weir \& Craig Mfg Co the court claims that "each is entitled to the fruits of his endeavours, taking no risk and expecting no reward from enterprises in which he does not choose to join". Blackledge v Weir, supra n. 45; Dunham v Railroad Co 7 Bissell 223 Fed Cas 4151 (1876); Lipscomb, supra n. 48, p. 450; Deller, supra n. 38, p. 1450; Gee, supra n. 48, p. 54. 
On the other hand, the freedom to solely decide upon exploitation strategies can cause potential problems. For instance, one of the co-owners can grant a non-exclusive licence to a competitor of the other co-owner, which can negatively affect business interests of the latter. ${ }^{51}$ Or even worse, one of the coowners can grant an exclusive licence to a competitor of the other owner. ${ }^{52}$ Moreover, the grant of multiple licences of a co-owned patent by one co-owner permits him to generate additional profit but at the same time "consumes" the value of the invention and diminishes it, preventing other co-owners from equally profiting from it. ${ }^{53}$ In addition, since the licencing strategies of co-owners do not have to be aligned, there is a chance that co-owners could grant an exclusive licence for the same scope more than once. Evidently, such "double licencing" is undesirable for the licencees, who pay a premium price for exclusivity, and may lead to conflicts.

In case of an assignment, the freedom to assign a share of a patent without the consent or accountancy can also have negative consequences. Since in the US a co-owner is allowed to assign a share of his interest in a co-owned patent, he and an assignee can both remain co-owners of the patent. Thus, one co-owner can expand the number of co-owners of the patent without the consent of other co-owners. Merges takes the view that this strategy of granting multiple assignments could be exploited "by a greedy co-owner". ${ }^{4}$ Such a co-owner obtains financial remuneration for assigning a share of his interest without losing

51 Paradiso and Pietrowski, supra n. 10, p. 196.

52 US default rules allow the co-owner to grant such a licence. As stated in Schering Corp $v$ Roussel-UCLAF SA the licence can be granted "on whatever conditions the co-owner chooses" (supra n. 46). However, the grant of such an exclusive licence will most likely lead to a conflict between the two co-owners, especially if the granted exclusive licence prevents the co-owner (to whose competitor the licence was granted) from using the co-owned patent. Nonetheless, as discussed in Section 3, it is unlikely that collaborating parties will follow default rules in practice. Collaborating parties will contractually forbid the grant of an exclusive licence (especially to a competitor) without the consent of one another.

53 Merges and Locke, supra n. 10, p. 595.

54 Ibid. 
the right to assign part of his interest to third parties multiple times. Those multiple assignments may negatively affect interests of other co-owners, since those sales may diminish the value of the patent. ${ }^{55}$

\subsubsection{French default rules on the exploitation of co-owned patents}

French default rules on exploitation of co-owned patents are less flexible than US default rules, as in some circumstances the consent or notification of other coowners is required. ${ }^{56}$ French legislation, similarly to the US, does not require a co-owner to obtain the consent from the other co-owners to use a co-owned patent. ${ }^{57}$

However, the French approach towards licencing of co-owned patents differs from the one in the US. L613-29 CPI makes a distinction between nonexclusive and exclusive licences. According to L613-29(d) CPI a co-owner may only grant an exclusive licence with the consent of all other co-owners or by the authorisation of the court. ${ }^{58}$ On the contrary, a non-exclusive licence can be granted without the consent. ${ }^{59}$ However, L613-29(c) CPI imposes an obligation to notify the draft of a licence agreement to other co-owners. ${ }^{60}$ In case one of the co-owners would like to oppose the grant of a licence, it can be done within three months of such notification, on the condition that the opposing co-owner will subsequently

55 Ibid.

56 Table 1.

57 CPI, L613-29(a). Joanna Schmidt-Szalewski and Nicolas Bouche, "Patents" in Hendrik Vanhees (ed.), France, International Encyclopaedia of Laws for Intellectual Property Law (Kluwer Law International, 2004), p. 133; AIPPI France, "The Impact of Co-Ownership of Intellectual Property Rights on their Exploitation" (2007), pp. 5 and 41, available at http://aippi.org/wpcontent/uploads/committees/194/GR194france.pdf (accessed 26 July 2019); Frédéric PollaudDulian, Propriété Intellectuelle: La Propriété Industrielle (Paris: Economica, 2011), p. 214; Laure Marino, Droit de la Propriètè Intellectuelle (Paris: PUF, 2013), p. 297; Nicolas Binctin, Droit de la Propriété Intellectuelle (Paris: LGDJ, 2010), p. 331.

58 Binctin, supra n. 57, p. 332; Pollaud-Dulian, supra n. 57, p. 214; Schmidt-Szalewski and Bouche, supra n. 57, p.133.

59 CPI, L613-29(c); Binctin, supra n. 57, p. 332; Schmidt-Szalewski and Bouche, supra n. 57, p. 133.

60 Binctin, supra n. 57, p. 332; Pollaud-Dulian, supra n. 57, p. 214; Schmidt-Szalewski and Bouche, supra n. 57, p. 133. 
acquire the share of a co-owner intending to grant such a licence. ${ }^{61}$ For this reason, a co-owner intending to grant a licence has to submit an offer for an assignment of his share and specify the price of an assignment together with the draft of a licence. ${ }^{62}$ Thus, the French approach does not per se limit non-exclusive licencing strategies of co-owners. However, it leaves the possibility for other coowners, first, to be informed about exploitation strategies of one another and, second, to oppose the grant of a non-exclusive licence, if necessary. Moreover, the need to acquire the shares of a patent ensures that a co-owner would only oppose the grant of a licence in extreme circumstances.

According to L613-29(e) CPI each co-owner has a right to assign his share of a patent. However, he is obliged to notify other co-owners about his decision to ensure that they can exercise their pre-emption right within three months from that notification. ${ }^{63}$

Contrary to the US approach, French law states that each co-owner who exploits the jointly owned invention is under obligation to pay an equitable compensation to the other co-owners who do not exploit the invention. ${ }^{64}$ This approach is, however, criticised by Binctin, who states that if everyone is free to exploit, it is strange that the one who decides to seize this opportunity is bound to share the "fruits" of the exploitation with co-owners, who are not proactive. ${ }^{65}$ He believes that the invention is per se valuable for the outside world and each co-owner is able to exploit it. However, the situation may be different if the invention is not perceived as valuable and is not easy to out-licence. The co-

61 CPI, L613-29(c); Binctin, supra n. 57, p. 332; Schmidt-Szalewski and Bouche, supra n. 57, p. 133.

62 CPI, L613-29(c); Binctin, supra n. 57, p. 332.

63 CPI, L613-29(e); Pollaud-Dulian, supra n. 57, p. 214; Binctin, supra n. 57, p. 133.

64 CPI, L613-29(a); Schmidt-Szalewski and Bouche, supra n. 57, p. 133; Pollaud-Dulian, supra n. 57, p. 214; Binctin, supra n. 57, p. 331. The amount of compensation is generally estimated based on the generated profits and the share of the co-owner, who does not exploit the invention (AIPPI France, supra n. 57, p. 41).

65 Binctin, supra n. 57, p. 131. 
owner, who lacks facilities to exploit the invention internally, may not be able to find an interested licencee, losing the single opportunity to generate revenue. Thus, the system established in France is aimed at defending interests of coowners who do not have sufficient opportunities to exploit an invention. The downside of this approach is that the "lazy" co-owner can free ride on the exploitation strategies of more proactive ones.

\subsubsection{Belgian default rules on the exploitation of co-owned patents}

According to Article XL.49 §2 CEL each of the co-owners has the right to use the invention independently. ${ }^{66}$ In Belgium the approach towards licencing of coowned patents is opposite to the one established in the US. In particular, according to Article XI.49 §2 CEL a co-owner can only grant a licence, exclusive or non-exclusive, with the consent of all other co-owners or, in case of failure, with the authorisation of a court. ${ }^{67}$

Each co-owner has the right to assign his share of a patent. ${ }^{68}$ Identically to French default rules, a co-owner does not have to obtain the consent of other coowners, however, he is obliged to notify them about the considered transaction,

66 Mireille Buydens, Droit des Brevets d'Invention et Protection du Savoir-faire (Brussels: De Boeck et Larcier, 1999), p. 188; AIPPI Belgium, "The Impact of Co-Ownership of Intellectual Property Rights on their Exploitation" (2007), p. 6, available at http://aippi.org/wpcontent/uploads/committees/194/GR194belgium.pdf (accessed 26 July 2019); Sophie Lens and Christophe Ronse, "Copropriété (et Partage) de Droits Intellectuels" in Dominique Kaesmacher (ed.), Les Droits Intellectuels (Brussels: Larcier, 2013), p. 553; Sophie Lens, "Coownership of Intellectual Property Rights under Belgian Law" (2016) 2 BMM Bulletin 75-83, p. 77; André Clerix et al., Octrooien in België: een Praktische Leidraad (Brugge: die Keure, 2016), p. 358.

67 Clerix et al., supra n. 66, p. 358; Buydens, supra n. 66, p. 188; Bernard Remiche and Vincent Cassiers, Droit des Brevets d'Invention et du Savoir-faire: Créer, Protéger et Partager les Inventions au XXIe Siècle (Brussels: Larcier, 2010), p. 409; Lens, supra n. 66, p. 78; Lens and Ronse, supra n. 66, p. 555; AIPPI Belgium, supra n. 66, p. 8.

68 CEL, art. XI.49 §2; Lens, supra n. 66, p. 79; Lens and Ronse, supra n. 66, p. 557. 
to permit them to exercise their pre-emption right within three months from the notification. ${ }^{69}$

Belgian legal provisions are silent about the obligation to share profits with other co-owners. ${ }^{70}$ Similarly to the US approach, according to Remiche and Cassiers, each co-owner is allowed to keep profits they make. ${ }^{71}$ Furthermore, Lens points out that "to the extent that each co-owner is able to exploit the joint right, everyone should be able to draw benefits from its personal use, without having to share its benefits with the other co-owners".$^{72}$ Lens bases her opinion on the fact that due to its intangible nature co-owners can simultaneously individually exploit the patent and generate profits, which is different in case of tangible property. ${ }^{73}$

\subsubsection{German default rules on the exploitation of co-owned patents}

German patent law, ${ }^{74}$ unfortunately, does not regulate the relationship between co-owners and does not contain any specialised rules governing co-owned patents and, thus, general provisions on co-ownership of civil law, specified in Title 17 of the German Civil Code (BGB), are applicable. ${ }^{75}$ Under Section 741 BGB co-owners are considered to be a community of part-owners by defined shares ${ }^{76}$ ("Bruchteilsgemeinschaft"). ${ }^{77}$ The general criticism of the provisions regulating

69 CEL, art. XI.49 §2; Lens, supra n. 66, p. 79; Clerix et al., supra n. 66, p. 358; Remiche and Cassiers, supra n. 67, p. 410; Lens and Ronse, supra n. 66, p. 558.

70 Lens, supra n. 66, p. 77; Lens and Ronse, supra n. 66, p. 554.

71 Remiche and Cassiers, supra n. 67, p. 409.

72 Lens, supra n. 66, p. 78.

73 Ibid.

74 Patentgesetz 1980 (PatG).

75 Haedicke and Timmann, supra n. 39, p. 253; AIPPI Germany, "The Impact of Co-Ownership of Intellectual Property Rights on their Exploitation" (2007), p. 1, available at http://aippi.org/wp-content/uploads/committees/194/GR194germany en.pdf (accessed 26 July 2019).

76 Further on the term "co-owners" is applied.

77 Feldges and Kramer, supra n. 39, p. 747; Klett, Sonntag and Wilske, supra n. 28, p. 8; Peter Hess and Kobler Michael, "Joint Intellectual Property Ownership in Germany" (2012) XLVII Les Nouvelles 271-273, p. 271; Haedicke and Timmann, supra n. 39, p. 60; Rudolf Krasser and 
co-ownership is that they are not detailed enough. ${ }^{78}$ According to Section 743(2) BGB each co-owner is authorised to use the joint object to the extent that joint use by other co-owners is not impaired. ${ }^{79}$ The scope of this provision is broad and requires specification. It refers not only to the right to use an invention but also to other exploitation rights, e.g. licencing. Following the wording of the legal provision, it is unclear which actions of one co-owner could impair the rights of other co-owners and, thus, require the consent.

Fortunately, legal doctrine sheds more light on the issue. Haedicke and Timmann acknowledge that "it is difficult to establish when such an impairment is likely, in view of the non-material nature of the invention and because this means that the own use by a part owner does not per se exclude the use of the invention by other part members".${ }^{80}$ They point out that the parallel use of the invention by all the co-owners is possible and the invention will not be necessarily "used up". ${ }^{81}$ This means that generally a use of an invention of one co-owner does not impair the use of other co-owners and, thus, the consent to use it is not required..$^{82}$

The approach to licencing of co-owned patents is similar to the Belgian one. In the absence of an agreement between co-owners, one co-owner is not allowed to grant any type of licence to a third party without the consent of all other coowners. ${ }^{83}$ A licence granted by only one owner without the consent of all co-

Christoph Ann, Patentrecht: Lehrbuch zum Deutschen und Europäischen Patentrecht und Gebrauchsmusterrecht (Munich: C.H. Beck, 2016), p. 366; AIPPI Germany, supra n. 75, p. 1; BGH X ZR 152/03 GRUR 663 (2005) - Gummielastische Masse II.

78 Hess and Michael, supra n. 77, p. 271.

79 Haedicke and Timmann, supra n. 39, p. 266; Klett, Sonntag and Wilske, supra n. 28, p. 8; Krasser and Ann, supra n. 77, p. 372; Feldges and Kramer, supra n. 39, p. 747.

80 Haedicke and Timmann, supra n. 39, p. 266.

81 Ibid.

82 Feldges and Kramer, supra n. 39, p. 747. Moreover, Krasser and Ann specify that the co-owner who uses the invention without the consent of others is not considered an infringer. Krasser and Ann, supra n. 77, p. 373.

83 Banks et al., supra n. 10, p. 60. 
owners would be invalid. ${ }^{84}$ It is considered that a grant of a licence goes beyond the simple use and in some circumstances can impair the joint use by other coowners. ${ }^{85}$

According to Section 747 BGB each co-owner can dispose his share of a patent. Thus, each co-owner has a right to independently assign his share of a patent to a third party. ${ }^{86}$ Co-owners do not have a pre-emption right, contrary to French and Belgian default rules. ${ }^{87}$

According to Section 743 I BGB, each co-owner is entitled to a fraction of the "fruits" corresponding to his share. Thus, in principle, a co-owner is not obliged to share the revenue with other co-owners. ${ }^{88}$ However, since the grant of a licence requires the consent of other co-owners, the issue of compensation will most probably be addressed in a licence agreement. The royalties will then be distributed between the co-owners in accordance with that agreement, or, in case of doubt, equally ${ }^{89}$ or in accordance with their respective shares in a patent. ${ }^{90,91}$

The German situation clearly shows that the fact that the co-ownership of tangible and intangible property is governed by the same provisions creates legal uncertainty. The existing provisions are not detailed and specific enough to govern the complex nature of intangible property. To increase legal certainty,

$84 \quad$ Ibid., p. 59.

85 Ibid., p. 60; Feldges and Kramer, supra n. 39, p. 748.

86 Krasser and Ann, supra n. 77, p. 375; Haedicke and Timmann, supra n. 39, p. 375; Winfried Tilmann, "Neue Überlegungen im Patentrecht" (2014) 10 GRUR 824-831, p. 828; Feldges and Kramer, supra n. 39, p. 747.

87 Hess and Michael, supra n. 77, p. 273.

88 Tilmann, supra n. 86, p. 827; Klett, Sonntag and Wilske, supra n. 28, p. 8; Haedicke and Timmann, supra n. 39, p. 267; Hess and Michael, supra n. 77, p. 272. For instance, in Gummielastische Masse II the court stated that a co-owner, personally using the invention, was not obliged to share his benefits with other non-using co-owners (Gummielastische Masse II, supra n. 77, p. 664; OLG Düsseldorf GRUR-RR 118 (2006) - Drehschwingungstilger; BGH GRUR 401 (2006) - Zylinderrohr).

89 BGB, s. 742.

90 BGB, s. 743 I.

91 Hess and Michael, supra n. 77, p. 272. 
similarly to other analysed jurisdictions, it would be desirable for Germany to adopt specialised default rules on patent co-ownership.

\begin{tabular}{|c|c|c|c|c|c|}
\hline \multirow{3}{*}{ Country } & \multicolumn{5}{|c|}{ Exploitation of a co-owned patent } \\
\hline & \multirow[t]{2}{*}{ Use } & \multicolumn{2}{|c|}{ Licencing } & \multirow{2}{*}{$\begin{array}{c}\text { Assignment } \\
\text { Personal share }\end{array}$} & \multirow{2}{*}{$\begin{array}{l}\text { Income } \\
\text { distribution }\end{array}$} \\
\hline & & Non-exclusive & Exclusive & & \\
\hline \multirow[b]{2}{*}{ US } & 35 U.S.C. 262 & \multicolumn{2}{|c|}{35 U.S.C. 262} & 35 U.S.C. 262 & $\begin{array}{c}\text { Blackledge } v \\
\text { Weir }\end{array}$ \\
\hline & Independently & \multicolumn{2}{|c|}{ Independently } & Independently & Not required \\
\hline \multirow[b]{2}{*}{ France } & L613-29(a) CPI & $\mathrm{L} 613-29(\mathrm{~d}) \mathrm{CPI}$ & $\begin{array}{l}\text { L613-29 } \\
\text { (d) CPI }\end{array}$ & L613-29(e) CPI & $\begin{array}{c}\mathrm{L} 613-29(\mathrm{c}) \\
\text { CPI }\end{array}$ \\
\hline & Independently & $\begin{array}{l}\text { Independently, } \\
\text { but with } \\
\text { notification of a } \\
\text { draft }\end{array}$ & Jointly & $\begin{array}{c}\text { Independently, } \\
\text { but with } \\
\text { notification, } \\
\text { pre-emption } \\
\text { right }\end{array}$ & Required \\
\hline \multirow[b]{2}{*}{ Belgium } & XI.49(2) CEL & \multicolumn{2}{|c|}{ XI.49(2) CEL } & XI.49(2) CEL & - \\
\hline & Independently & \multicolumn{2}{|c|}{ Jointly } & $\begin{array}{c}\text { Independently, } \\
\text { but with } \\
\text { notification, } \\
\text { pre-emption } \\
\text { right }\end{array}$ & Not required \\
\hline \multirow[b]{2}{*}{ Germany } & $743(2) \mathrm{BGB}$ & \multicolumn{2}{|c|}{$\begin{array}{c}747 \text { BGB } \\
\text { Gummielastische Masse II }\end{array}$} & 747 BGB & 743 I BGB \\
\hline & Independently & \multicolumn{2}{|c|}{ Jointly } & Independently & Not required \\
\hline
\end{tabular}

Table 1: Default rules on exploitation of co-owned patents

To conclude, the default rule on the allocation of ownership of joint developed inventions of selected jurisdictions is based on inventorship. In R\&D 
partnerships collaborating organisations, which employees jointly developed an invention, become co-owners of a patent upon successful patent prosecution. Collaborating parties, co-owners of a patent, would then be required to exploit co-owned patents jointly in line with national default rules. ${ }^{92}$ Each of those default rules has certain advantages and disadvantages, which may suit interests of one of the co-owners more than another. However, the biggest disadvantage of default rules that govern exploitation of co-owned patents (in the absence of the agreement to the contrary) is that they significantly vary depending on the jurisdiction. Since patents are territorial in nature, the exclusive rights are only granted in the territory of a country in which a patent was granted. Consequently, if collaborating parties obtain protection in multiple countries, they would need to exploit each national co-owned patent in accordance with respective national default rules, even if those patents belong to the same patent family and are subject to the same transaction. ${ }^{93}$ For those reasons, lawyers often advise organisations to contractually specify the terms of joint exploitation of coowned patents from the same patent family. ${ }^{94}$

92 Figure 3 and Table 1.

93 For further information on the law applicable to co-owned patents see Gorbatyuk, Van Overwalle and van Zimmeren, supra n. 1, p. 278.

94 Feldges and Kramer, supra n. 39, p. 749. 


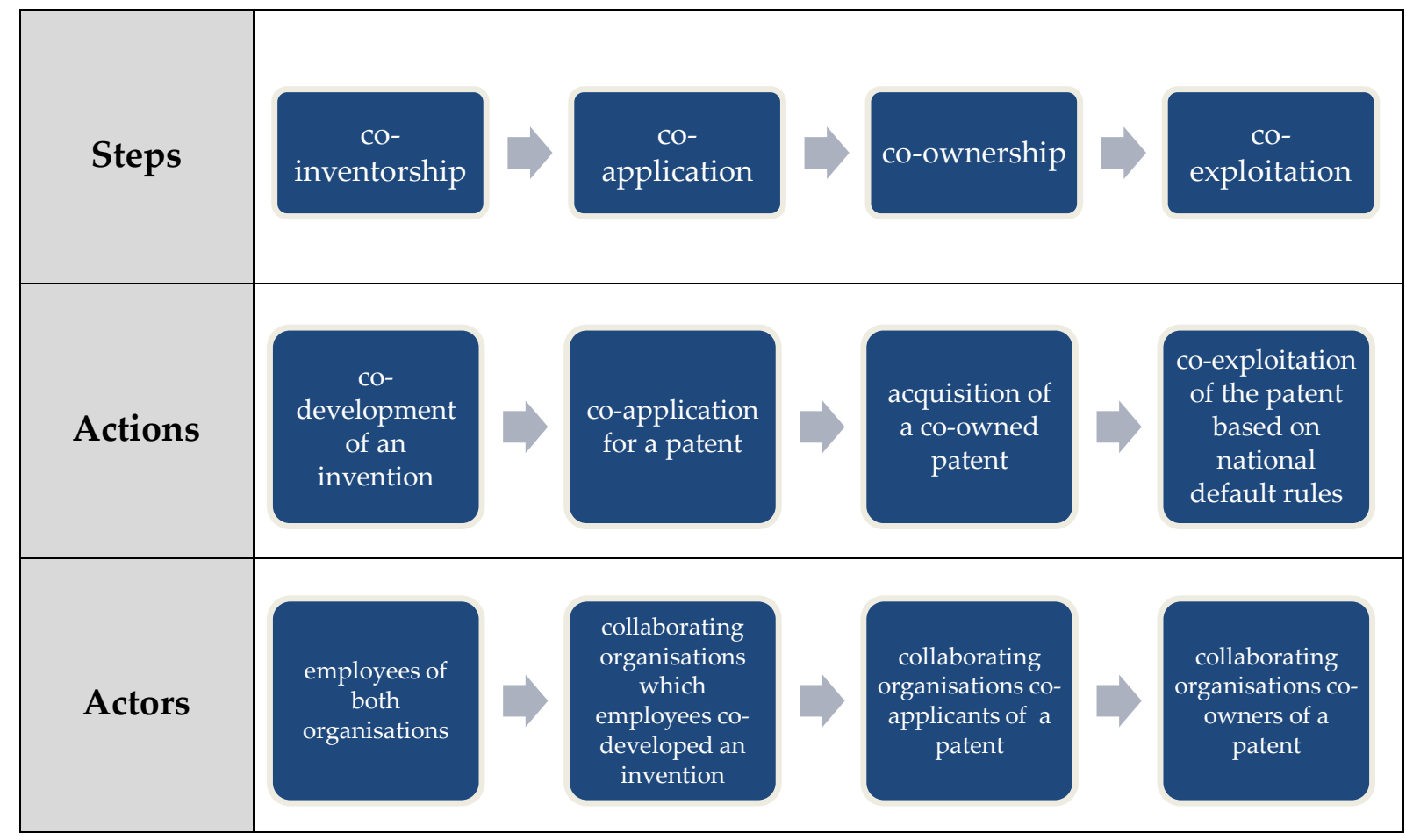

Figure 3: "Default regime" to allocate ownership of jointly developed inventions and related exploitation rights [Scenario 1]

Let us look back at the example provided in Figure 1. If $\mathrm{A}$ and $\mathrm{B}$ do not contractually specify the rules applicable to the allocation of ownership of jointly developed inventions generated in the framework of their R\&D partnership, the R\&D outcomes will be co-owned and exploited in accordance with related national default rules. Since A is located in the US and B in France, they would be interested in obtaining patent protection at least for the territory of the US and France. Due to the territorial nature of patents, the US co-owned patent will be governed by US default rules and the French co-owned patent by French default rules. ${ }^{95}$ Not only those default rules significantly differ, they also may not be in line with business interests of at least one of the co-owners. For instance, A cannot prevent B from giving a licence for the US co-owned patent, for instance, to a competitor of A. Thus, the differences in national default rules may cause

95 Supra n. 93. 
misunderstandings and create conflicts.

\section{Contractual practices on the allocation of patent ownership of jointly developed inventions and exploitation rights}

The principle of freedom of contract, being one of the main principles of contract law, permits collaborating parties to contractually establish rules applicable to their relationship. ${ }^{96}$ In particular, collaborating parties can contract out of default rules identified in the legislation and establish rules which fit their IP strategy better. Contractual freedom, however, can be limited at times by mandatory rules of, for instance, contract law, IP law, labour law, and competition law. ${ }^{97}$ Mandatory rules have to be respected and cannot be overruled. ${ }^{98}$ For instance, collaborating parties cannot contractually modify the term of protection or the granted scope of exclusive rights of patent owners (vis-á-vis third parties), since those rules are mandatory, but they are free to contractually agree upon the allocation of patent ownership and the exploitation of co-owned patents. ${ }^{99}$

96 Gorbatyuk, Van Overwalle and van Zimmeren, supra n. 1, p. 282; Jan Smits, "The Law of Contract" in Jaap Hage and Bram Akkermans (eds.), Introduction to Law (Springer International Publishing, 2014), p. 53. For further information see Section 4.

97 For more information on limits of competition law on contractual freedom in R\&D partnerships consult Arina Gorbatyuk, "R\&D agreements and EU competition law: when can companies be 'safe'?" (2018), available at < https://www.law.kuleuven.be/citip/blog/rdagreements-and-eu-competition-law-when-can-companies-be-safe/> (accessed 26 July 2019). As for the mandatory rules of labour law, collaborating parties should pay attention to employee's rights to compensation. For further information consult Marie-Christine Janssens, "EU Perspective on Employees' Invention" in Ann Monotti and John Duns (eds.) Business Innovation and the Law (Edward Elgar, 2013) pp. 111-130; Sanna Wolk," Remuneration of Employee Inventors - Is There a Common European Ground? A Comparison of National Laws on Compensation of Inventors in Germany, France, Spain, Sweden and the United Kingdom" (2011) 42(3) International Review of Intellectual Property and Competition Law 272-298; Morag Peberdy and Alain Strowel, "Employee's Rights to Compensation for Inventions - a European Perspective" (2009) 10 Life Science 63-70.

98 Ayres and Gertner, supra n. 5, p. 87; Randy Barnett, "The Sound of Silence: Default Rules and Contractual Consent" (1992) 78(4) Virginia Law Review 821-911, p. 822; Smits, supra n. 96, p. 53.

99 Gorbatyuk, Van Overwalle and van Zimmeren, supra n. 1, p. 282. 
According to the data acquired through semi-structured interviews, organisations, regardless of their size, type or location, never follow the default regime (Scenario 1) ${ }^{100}$ suggested by the legislator and prefer to contractually specify applicable rules. ${ }^{101}$ The default regime is not optimal primarily since, as the representative of the Company 3 explained, the unharmonised nature of national default rules creates a high level of uncertainty, especially in an international framework:

We never follow the default arrangement by law simply because it is different country to country. Many people think that since you are a Belgian company, the Belgian patent law applies to that family of patents. But that is not true. If the family of patents contains a US patent, it is US patent law that provides the default arrangements. ${ }^{102}$

Contractually establishing a specific approach towards exploiting co-owned patents from the same patent family is clearly preferred. After analysing the acquired data, two main contract-based regimes ${ }^{103}$ were identified, a so-called

\footnotetext{
100 Figure 3.

101 Annex II.

102 Interview with Interviewee 1 from Company 3 (C 3) (Belgium, 17 March 2015).

${ }^{103}$ For the purpose of simplification, the contractual practices were classified into two main scenarios. In practice, however, they may be subdivided depending on multiple technicalities, e.g. how exploitation rights are divided between collaborating organisations. One could also go into more detailed analysis depending on the type and size of actors or jurisdiction. The responses of the interviewees provided in footnotes are selected examples from a bigger sample of responses. More detailed analysis and broader overview of responses are provided in my $\mathrm{PhD}$ entitled "Rethinking Intellectual Property Ownership in the Context of Open Innovation" (2019; to be published). For the brief overview of the main findings of my research see Arina Gorbatyuk, "Ph.D. Defence: Rethinking Intellectual Property Ownership in the Context of Open Innovation" (2019), available at https://www.law.kuleuven.be/citip/blog/phd-defence-rethinking-intellectual-property-ownership-in-the-context-of-open-innovation/ (accessed 26 July 2019).
} 
"hybrid regime" (Scenario 2) ${ }^{104}$ and "sole ownership regime" (Scenario 3). ${ }^{105,106}$ Overall, it is concluded that Scenario 3 is the most preferred contractual regime, especially by MNEs; Scenario 2 is considered to be the second-best option. Scenario 1 , the default regime, ${ }^{107}$ is never followed by the interviewed organisations. ${ }^{108}$

\subsection{Hybrid regime}

According to the "hybrid regime" collaborating parties decide to co-own patents but, differently from the "default regime", contractually specify how co-owned patents should be exploited. Those exploitation rules will then be applicable to all co-owned patents related to the $R \& D$ partnership. If those contractually established rules are detailed and precise enough, there would be no need to consult national default rules to fill in the contractual gap. This regime is referred to as "hybrid" since collaborating parties allocate ownership of jointly developed inventions based on inventorship (in principle ${ }^{109}$ ), as prescribed by the legislator, but refrain from following national patent exploitation default rules.

\footnotetext{
104 Figure 4.

105 Figure 5.

106 It must be specified that the classification applied in this article is deliberately simplified and differs from the one used in my Ph.D. dissertation (supra n. 103). In my dissertation, I specify five scenarios: (1) Scenario 1 "Legal Default Inventorship"; (2) Scenario 2 "Contractual Inventorship"; (3) Scenario 3 "Contractual Single Sole Ownership"; (4) Scenario 4 "Contractual Dual Sole Ownership (+ Co-ownership)"; and (5) Scenario 5 "Contractual Coownership".

107 Figure 3.

108 Annex II.

109 The decision to co-own patents in the "hybrid regime" may not always be based on the actual co-inventorship. At times, one of the organisations, which is not actively involved in the development of an invention, "earns" its share of a patent for, for instance, providing the underlying background IP.
} 


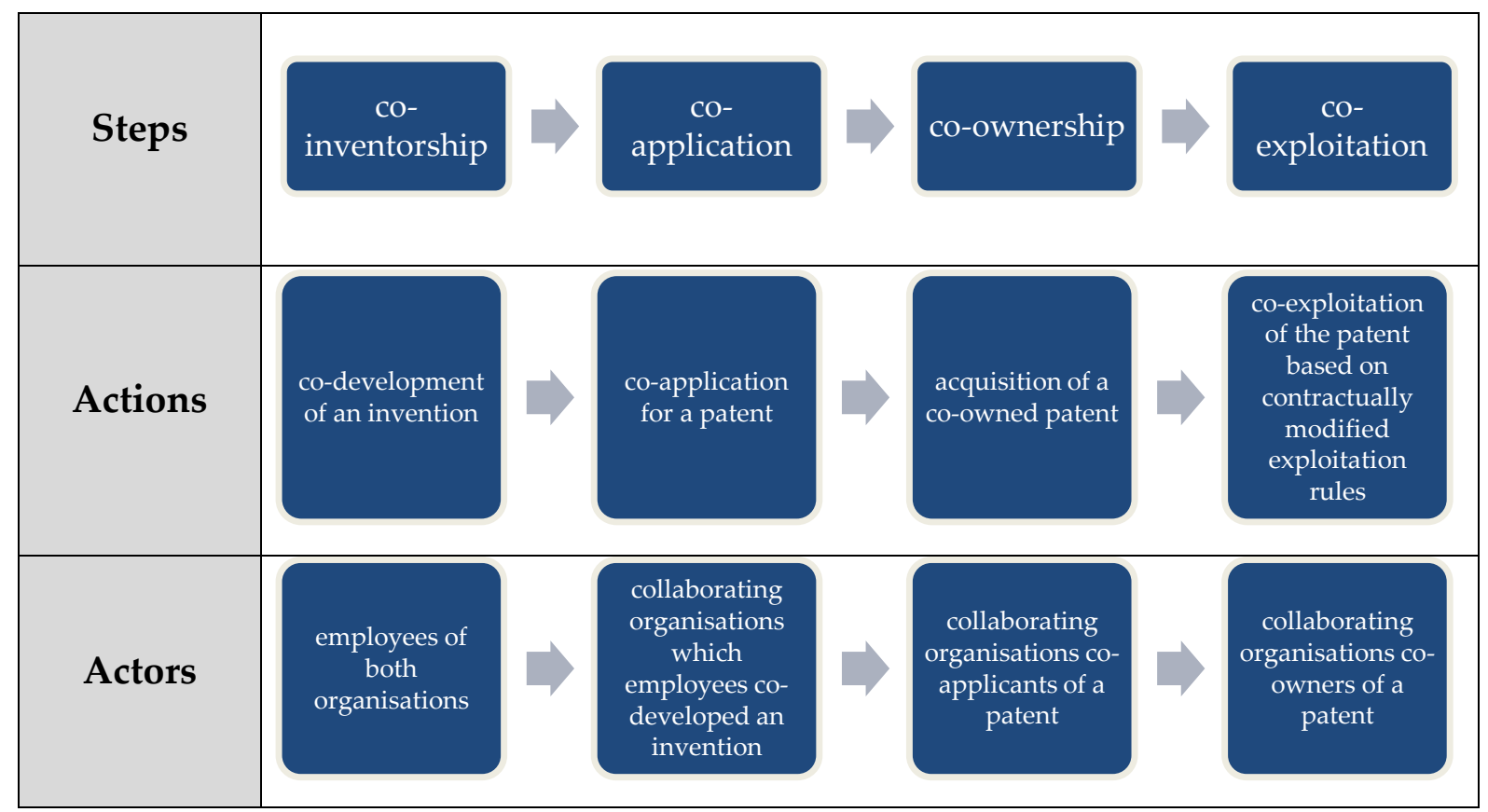

Figure 4: "Hybrid regime" to allocate ownership of jointly developed inventions and related exploitation rights [Scenario 2]

This Scenario is quite common for joint R\&D projects between universities. ${ }^{110}$ The "hybrid regime" permits universities, by sharing the ownership equally, to acknowledge the contribution of each party.

Furthermore, collaborations between a university and a company (regardless of the size) may at times lead to co-ownership of jointly developed inventions. In particular, $R \& D$ results generated in the framework of $R \& D$ collaboration agreements ${ }^{111}$ may be co-owned between a Belgian university and an industrial partner. ${ }^{112}$ The ownership allocation process may sometimes be

110 Interview with Interviewee 1 from TTO 1 (Belgium, 8 October 2015); Interview with Interviewee 1 from TTO 2 (Belgium, 2 December 2016).

111 Supra n. 18 for the definition.

112 TTO 1, supra n. 110: "In general we like to at least co-own a patent or own it if the company does not have any inventors". In addition, Belgian universities may at times insist on coownership for visibility and future funding opportunities and this approach may be approved by companies. Interview with Interviewee 1, C 1 (Belgium, 24 February 2015): “One of our main partners [a Belgian university] is judged on the number of patents they file every year...They can have the patent first for the statistics". 
influenced by the amount of financial remuneration offered by a company. ${ }^{113}$ $R \& D$ results generated in the framework of $R \& D$ contract research agreements ${ }^{114}$ are typically owned by companies. ${ }^{115}$ US universities, on the contrary, have a very strong position towards ownership of inventions developed by their academic staff. They claim that ownership is never assigned; and it is always divided based on inventorship. ${ }^{116}$ This strict policy is significantly aided by the Bayh-Dole Act. ${ }^{117}$ Some interviewed companies suggest that some German universities are also reluctant to give their ownership away. ${ }^{118}$

The "hybrid regime" could be selected in situations when collaborating companies have similar expertise ${ }^{119}$ or are active in different industry sectors and cannot divide patent claims depending on the field of technology of their interest. ${ }^{120}$

113 TTO 1, supra n. 110: "Most of the time we would like to have ownership for at least $50 \%$, or at least to be on the patent we generated...They can ask for other types of regulations. But at least we should be rewarded in one way or another, either get money for it upfront, or get return percentage, royalties"; TTO 2, Interviewee 1, supra n. 110: "It really depends on how much they pay. If they fully pay it, then taxpayers' money is not involved. In that case we agree that they own the foreground IP. But that also means they have fully paid for it and preferably even with some margin on it"; Interview with Interviewee 1, C 6 (Belgium, 24 March 2015): "With other universities [not US ones] we always try to have full ownership. And what they will get then is some kind of fair share, an equitable share, when something commercial comes up".

114 Supra $\mathrm{n} .17$ for the definition.

115 See subsection 3.2.

116 C 6, supra n. 113: "If it is with US universities, we mostly need to agree on joint IP"; Annex II.

117 Title 37 Code of Federal Regulations (CFR) Part 401 (37 CFR 401). For more information on the Bayh-Dole Act see Vanessa Bell, "The State Giveth and the State Taketh Away: Patent Rights under the Bayh-Dole Act" (2014) 24 Southern California Interdisciplinary Law Journal 491528, p. 492; Emily Morris, "The Many Faces of Bayh-Dole" (2016) 54 Duquesne Law Review 81132, p. 82.

${ }_{118}$ C 1, Interviewee 2, supra n. 112: "German universities are very reluctant to give full ownership to us and the US is even worse".

119 Since MNEs rarely collaborate with their direct competitors, the described approach may be applied in collaborations between an MNE and an SME; an SME and an SME; or an MNE/SME and an RI. Interview with Interviewee 1 from RI 1 (Belgium, 3 March 2015): "If you have similar expertise, that development should be co-owned".

${ }_{120}$ See subsection 3.2 . 
The "hybrid regime" is applied for jointly developed inventions generated in the framework of pre-competitive research projects and/or consortia. ${ }^{121} R \& D$ outcomes arising out of those collaborative initiatives are generally fundamental in nature. None of the parties can assess the value of the invention and its commercialisation potential at that moment. ${ }^{122}$ Thus, it is not feasible to apply allocation strategies specified in Scenario 3. For example, the fundamental nature of those inventions might render it impossible to divide patent claims depending on the field of technology. Moreover, companies, collaborating in precompetitive research projects, are generally active in the same industry sector and have the same position in the supply chain. ${ }^{123}$

Overall, almost all interviewed MNEs expressed their negative feelings towards patent co-ownership. They prefer to avoid both the "default regime" and the "hybrid regime" unless it is impossible. It is easier to manage the large patent portfolio and exploit the patents if they are solely owned. For instance, the representative of the Company 8 stated:

I hate co-ownership applications. As often as I can I will avoid it because it is always very complicated. First of all, you have to define who will take care of the prosecution of the application, who will draft it. Secondly, if you have co-ownership, you really need to define some rules of co-ownership: Who

121 Supra $\mathrm{n} .19$ for the definition. Interview with Interviewee 1 from C 2 (the Netherlands, 10 March 2015): "If it is a consortium agreement - co-ownership of joint inventions".

122 Interview with Interviewee 1 from C 8 (Belgium, 14 May 2015): "It is really more exploratory. It is more theoretical, it is very upstream in the chain. We are very far from the final product that will end up with our consumers".

${ }^{123}$ The majority of companies stated that they do not collaborate with competitors. Some interviewees specified that they at times collaborate with competitors but only in precompetitive research or in the field of technology in which they are not direct competitors. C 1, supra n. 112: "[We collaborate] with competitors very little. It is too dangerous, we do not trust them, we try to avoid collaborating with competitors"; C 1, Interviewee 2, supra n. 112: "We have certain areas where we do pre-competitive research together"; Interview with Interviewee 1 from C 33 (the Netherlands, 28 April 2017): "We collaborate on aspects where we are not competing directly. Normally we do not collaborate with direct competitors". 
will do what? Who can exploit what? What to do in case one of the partners is no longer interested in obtaining patent protection in a specific country? All these have to be prepared in advance and negotiated. It is very boring to try to negotiate that. ${ }^{124}$

It is also important to briefly elaborate upon how exploitation rights can be allocated in Scenario 2. In practice collaborating organisations adjust exploitation rules according to their preferences, ${ }^{125}$ without refereeing to any national default rules in a contract. Moreover, some interviewees pointed out that they were not even familiar with the content of default rules. ${ }^{126}$

Furthermore, in addition to that approach (or instead of it), collaborating parties can safeguard the important exploitation rights by way of licences. First, one co-owner can grant an exclusive licence to the other co-owner for the full scope of a patent or for a particular field. Such licence may be given, for instance, by a university to a company that intends to commercialise the technology. ${ }^{127}$ Second, co-owners can divide exclusive fields in which they could exploit the coowned patent independently. ${ }^{128}$ This strategy is applicable to situations when companies either have different position in the supply chain (e.g. suppliercustomer relationship) or are active in different industry sectors. ${ }^{129}$

124 C 8, supra n. 122.

125 For instance, it can be established that each co-owner can use the co-owned patent without the consent, but the consent is to be acquired in case of grant of a licence.

126 Interview with Interviewee 1 from C 5 (Belgium, 27 April 2015): “We never follow national rules, I am not even aware of them".

127 C 6, supra n. 113: "There is an exclusive licence given, so it is one party that exploit it, even when it is co-owned. And then there is a distribution of income, royalties that are going the other way around".

128 C 6, supra n. 113: "Mostly, for commercial purposes it is one of the parties that can do that [exploit]. Of course, you can also divide it in different markets"; Interview with Interviewee 1 from C 9 (Belgium, 10 June 2015): "I think sometimes it is easier to give them [universities] coownership and negotiate their rights, exclusivity in certain domains".

129 This strategy is often selected when it was not possible to divide the claims and obtain solely owned patents. 


\subsection{Sole ownership regime}

According to the "sole ownership regime", the right to apply for a patent or a granted patent is assigned to only one of the collaborating parties. ${ }^{130}$ The organisation to whom the right to apply for a patent has been assigned, subsequently solely applies for a patent. In case of successful patent prosecution, the organisation, which applied for a patent, becomes the sole owner of the patent and, thus, can solely exploit it. This organisation may in some circumstances, grant a licence to the partner organisation, which assigned its right to apply for a patent, on different conditions.

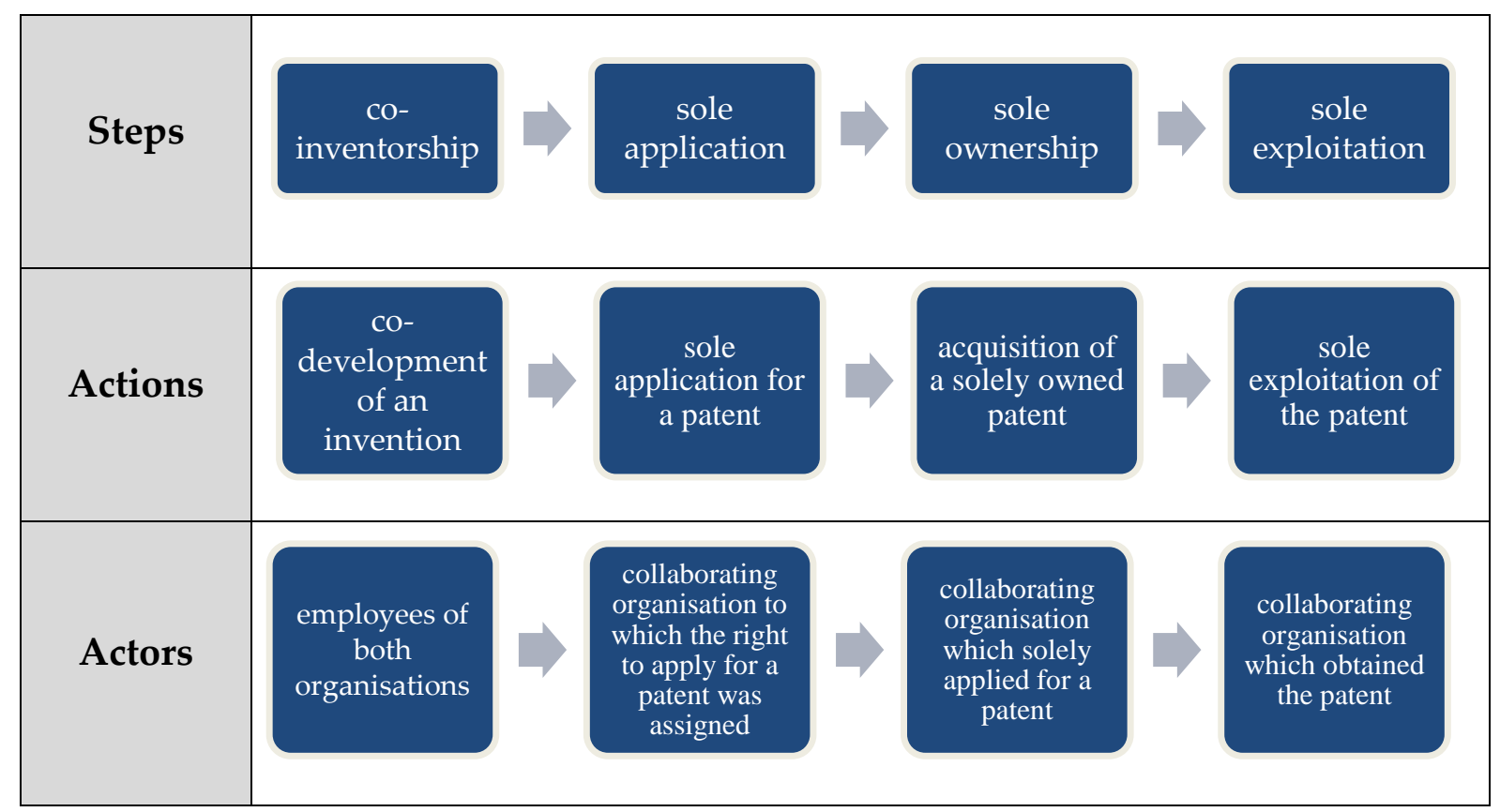

Figure 5: "Sole ownership regime" to allocate ownership of jointly developed inventions and related exploitation rights [Scenario 3]

This Scenario is chosen, for instance, in contract research or service agreements between a university or a research institution and a company. In this setting, a university or a research institute is hired by a company to conduct particular

\footnotetext{
${ }^{130}$ Figure 5.
} 
research or provide a service. Generally, the company bears all the costs and associated risks in return for the sole ownership. ${ }^{131}$ The exception is US universities, which, as indicated above, are reluctant to transfer ownership. However, they are often willing to grant an exclusive licence to the sponsoring party on different conditions.

This regime is also actively used in collaborations between companies (regardless of their size) when they either have different positions in the supply chain (e.g. supplier-customer relationships) or are active in different industry sectors (e.g. R\&D projects between a software company and a chemical company). ${ }^{132}$ The ownership allocation depends on the type of invention or on its subject matter. For example, a supplier will solely own patents that relate to the product and the customer - to its application. ${ }^{133}$ Similarly, a software company will solely own IT-related patents and a consumer electronics company - patents related to their product. Thus, the decision of ownership allocation is based rather on the opportunities for patent exploitation than on the inventorship. In particular, collaborating parties assess which one of them is best placed to exploit the invention. If at times patent claims cannot be divided into separate patent applications, collaborating companies may decide to follow Scenario 2. ${ }^{134}$

${ }^{131}$ Interview with Interviewee 1 from C 4 (Belgium, 24 March 2015): “We pay for it and we want to have the IP"; $\mathrm{C} 8$, supra n. 122: "We try to refuse co-ownership. The principle is very simple: we pay for everything, we get everything"; TTO 1, supra n. 110: "In contract research it is mostly the company that pays for it and then also gets all the rights of the returns".

132 Interview with Interviewee 1 from C 7 (Belgium, 7 May 2015): “We try to make such a split that each party has the IP rights that really fit with their strategic core business...You can put all of that in one patent application, but we try to divide it"; Interview with Interviewee 1 from C 18 (Belgium, 29 November 2016): "Our standard point of negotiation is always a division according to the field"; C 33, supra n. 123: "Preferable solely owned. It could be split up: A gets a patent on products; B - on certain application".

133 In supplier-customer relationships companies may also negotiate an exclusivity period during which the customer is obliged to purchase products from the supplier to prevent the customer from switching to another supplier after the necessary technology is developed. Competition law aspects in this case need to be carefully considered.

${ }^{134}$ C 6, supra n. 113: "We divide the technology...If it is really combined, then we say: it is joint. But [we accept it] only in very exceptional circumstances"; Interview with Interviewee 1 from 
To conclude, MNEs generally favour the "split the IP" approach or keeping ownership for themselves. ${ }^{135}$ However, some interviewees explain that even though the discussion about the ownership of (jointly) developed inventions is important and they generally prefer to solely own R\&D outcomes, it is not as important as ensuring that they obtain the necessary scope of exploitation rights (for instance, in the form of an exclusive licence). ${ }^{136}$ They are willing to compromise on the former but would be reluctant to compromise on the latter. Furthermore, it was also suggested that if the field and the scope of exclusivity for one of the co-owners is defined very broadly "it is almost sole ownership" ${ }^{137}$

C 14 (Belgium, 23 July 2015): “In application it can be touching each other and then it is a joint patent and we put both names on it".

135 C 2, supra n. 121: "In general we prefer sole ownership because there is a high administrative burden linked to joint ownership"; C 3, supra n. 102: "We want to avoid joint IP. Why? Because, if the project terminates unsuccessfully, joint IP is always a problem"; C 5, supra n. 126: "We opt for sole ownership because of decision-making. The issue with co-owned IP is that you have two decision makers for deciding what the next step is"; C 7, supra n. 132: "We try to avoid that. Co-ownership generates too many issues"; Interview with Interviewee 1 from $C$ 15 (Belgium, 24 September 2015): "Very rarely, we try to avoid that [co-owned patents] as much as possible, because they are huge headaches"; C 33, supra n. 123: "We do not favour coownership due to the legal uncertainty and need to ask permission for all actions"; Interview with Interviewee 1 from C 35 (Belgium, 12 May 2017): "What we try to avoid as much as possible is joint ownership. Just because we are a global company and each country deals with joint ownership differently".

136 C 1 , supra n. 112: "What is important to us is to have some kind of exclusivity even if we are limited in time and with as wide territory as possible. If we have an exclusive licence, then it is fine"; C 18, supra n. 132: "If you have a serious competitive advantage with respect to competition, you can always accept co-ownership or even ownership by the other party. But you must at least have an easy access to a non-exclusive agreement or a possibility for exclusivity at decent terms"; C 9, supra n. 128: "I think sometimes it is easier to give them coownership and negotiate their rights, exclusivity in certain domains back and so on."

${ }_{137}$ C 1, Interviewee 2, supra n. 112: "We need an exclusive field for exploitation, and we try to define the scope very broadly, so we have rights very similar to the ownership. If we describe very broadly the field, the scope, the material and the geographical fields and then all the right of use very broadly for us, then it is almost sole ownership." 
SMEs also prefer to own patents related to their core expertise, if possible. ${ }^{138}$ Some SMEs are less negative ${ }^{139}$ about co-ownership than others. ${ }^{140}$ Moreover, when collaborating with MNEs, SMEs are generally not the parties which bring the final product to the market. Thus, they are willing to give the broader scope of exploitation rights to the partner with a commercial facility. ${ }^{141}$ TTOs are generally not against the "hybrid regime". ${ }^{142}$ The main difference between TTOs from US and non-US universities is that US universities do not assign ownership for inventions generated by their academic staff in view of their Bayh-Dole obligations, thus, they never follow Scenario 3. On the other hand, Belgian universities, for instance, do not have such a strict policy and often assign ownership to their collaborating parties, especially in the framework of contract research.

Let us look back one more time at the example provided in relation to Figure 1. Following the practices of the interviewed organisations, it can be suggested that A and B would primarily opt to follow Scenario 3. A and B are active in different fields: $\mathrm{A}$ is a pharmaceutical company whereas $\mathrm{B}$ is a medical equipment company. Thus, inventions which are related to the field of expertise of A will be owned by it. Similarly, inventions which are primarily related to the field of expertise of B will belong to B. If for some inventions patent claims cannot be divided, A and B may consider following Scenario 2.

\footnotetext{
${ }_{138}$ C 6, supra n. 113: "Mostly we ask for sole ownership, as far as it related to our technology".

139 C 4, supra n. 131: "That is more the collaboration type, both pay, and the result is also for both then".

140 C 6, supra n. 113: "We try to avoid it as much as possible".

${ }^{141}$ C 6, supra n. 113: "Mostly, in case of universities, it is us that will exploit it [a patent], even if it is co-owned. In case of collaborations with industry, then mostly they will exploit it".

142 Annex II.
} 


\section{The interface between patent default rules and contractually established rules: why default rules are not "sticky"?}

The legal rules of contracts are divided into default (or mutable) rules and mandatory (or immutable) rules. ${ }^{143}$ Mandatory rules "displace freedom of contract", whereas default rules can be modified according to preferences of contractual parties. ${ }^{144}$ The primary function of default rules is to fill gaps in incomplete contracts or regulate the matter in the absence of contracts. ${ }^{145}$ It is considered by legal scholars that default rules should reflect what contractual parties would have contractually established. ${ }^{146}$ "Majoritarian" default rules facilitate contract negotiation processes by providing parties with a preferred option (the one they would not change) which decreases "contracting costs". ${ }^{147,148}$ Consequently, the secondary function of default rules is to facilitate contract negotiations and decrease contracting costs.

Based on the classification of default rules suggested by Schwartz, ${ }^{149}$ default rules on the allocation of ownership of jointly developed inventions are

\footnotetext{
143 Ayres and Gertner, supra n. 5., pp. 87-88; Schwartz, supra n. 7, p. 390; Smits, supra n. 96, p. 53.

144 Ayres and Gertner, supra n. 5, p. 87; Barnett, supra n. 98, p. 822; Smits, supra n. 96, p. 53.

145 Ayres and Gertner, supra n. 5, p. 87; Smits, supra n. 96, p. 53.

146 Ayres and Gertner, supra n. 5, p. 89; Ben-Shahar and Pottow, supra n. 15, p. 651.

147 Alan Schwartz and Joel Watson, "The Law and Economics of Costly Contracting" (2004) 20(1) Journal of Law, Economics, \& Organization 2-31, 2; Nicholas Argyres and Kyle Mayer, "Contract Design as a Firm Capability: An Integration of Learning and Transaction Cost Perspectives" (2007) 32(4) Academy of Management Review 1060-1077, p. 1060. The academic literature on contracting costs is also closely related to the literature on bargaining costs David Haddock and Fred McChesney, "Bargaining Costs, Bargaining Benefits, and Compulsory Nonbargaining Rules" (1991) 7(2) Journal of Law, Economics, \& Organization 334-354, p. 334; Douglas Bosse and Sharon Alvarez, 'Bargaining power in alliance governance negotiations: evidence from the biotechnology industry' (2010) 30 Technovation 367-375, p. 367.

148 Schwartz, supra n. 7, p. 399; Ben-Shahar and Pottow, supra n. 15, p. 651; Ayres and Gertner, supra n. 16, p. 1592; Hesselink, supra n. 8, p. 46; Storme, supra n. 15, p. 237.

149 According to Schwartz there are six types of default rules in contract law: (1) problem-solving defaults; (2) equilibrium-inducing defaults; (3) information-forcing defaults; (4) normative defaults; (5) transformative defaults and (6) structural defaults. Schwartz, supra n. 7, p. 390.
} 
normative in nature. Normative default rules are in essence "fairness-based default rules" that are "enacted to bring about fair or just states of affairs". ${ }^{150}$ By prescribing the allocation of ownership based on inventorship, default rules are aimed at safeguarding a "fair" distribution of ownership. The intention is to acknowledge and reward intellectual efforts of all inventors which contributed to the invention (the principle of fairness). Furthermore, default rules provide coowners of a patent with an equal "bundle" of exclusive rights (the principle of equal treatment). Even though the actual method of exercising those rights differs depending on the jurisdiction, they have to be exercised according to the same relevant national default rules by each co-owner. For instance, each co-owner of a Belgian patent would need to obtain the consent from other co-owners to grant a licence to a third party.

Even though default rules attempt to safeguard such important principles as fairness and equal treatment, based on the acquired data, it has been observed that they are not followed at all or followed to some extent in a "hybrid" form. ${ }^{151}$ Collaborating organisations always contractually specify rules on the allocation of ownership of jointly developed inventions and related exploitation rights when engaging in $R \& D$ partnerships and never blindly rely on default rules. According to Schwartz "good default rules 'stick' while bad defaults do not" ${ }^{152}$ Following this statement, it can be suggested that the existing default rules on patent ownership are "bad" since they do not "stick". Two follow-up questions arise: (1) Why are current default rules in this field so "bad"?; and (2) Can the legislator implement "better" default rules?

\footnotetext{
150 Ibid., p. 402.

151 Annex II.

152 Schwartz, supra n. 7, p. 399.
} 


\subsection{Why are current default rules "bad"?}

Default rules are not followed for two main reasons. First, they are not followed because they contradict business interests of at least one of collaborating organisations, especially companies. The goal of many companies is to ensure that they solely own patents valuable for their business or at least have the necessary scope of exclusive rights. This strategy allows them to exploit patents without coordinating their actions with other parties, which is less time consuming, less costly, and more efficient. Default rules do not consider commercial interests or financial contributions of collaborating organisations and prioritise rewarding equal intellectual efforts of organisations and their employees. The "hybrid regime" is primarily acceptable in collaborative settings when none of the parties have particular commercial interests linked to the developed invention. For instance, co-ownership regime between two academic institutions is accepted since, despite an increase in commercial activities of universities (e.g. by establishing TTOs or spin-offs), ${ }^{153}$ profit-making and developing commercial products is not a primary objective of academia. ${ }^{154}$ In general, their main missions are to educate, to conduct (often fundamental) research, and to disseminate their expertise, knowledge, and scientific discoveries. ${ }^{155}$

Second, default rules require significant amount of coordination between organisations and create high level of uncertainty related to exploitation of coowned patents. As highlighted multiple times, national default rules differ. Thus, in international settings collaborating organisations would need to exploit

153 Donald Siegel, Reinhilde Veugelers, and Mike Wright, "Technology Transfer Offices and Commercialization of University Intellectual Property: Performance and Policy Implications" (2007) 23(4) Oxford Review of Economic Policy 640-660, p. 640.

154 Gorbatyuk, Van Overwalle and van Zimmeren, supra n. 1, p. 287.

155 Anthony Boccanfuso, Researcher Guidebook: A Guide for Successful Institutional-Industrial Collaborations (Atlanta: UIDP 2012), p. 11. 
national co-owned patents in accordance with the applicable set(s) of national default rules.

\subsection{Can the legislator implement "better" default rules?}

According to the general view of legal scholars, default rules should "mimic efficient arrangements", otherwise these rules will impose unnecessary contracting costs. ${ }^{156}$ Thus, in order to establish so-called "majoritarian" default rules, legislators would need to ensure that new default rules embrace current contractual preferences of organisations.

The first issue that arises is how to decide whose contractual preferences legislators should prioritise. Should they prioritise commercial companies, universities or inventors? Since the data used for this paper were collected in the framework of a research project focused on OI, the majority of interviewed organisations are companies. Consequently, if one proposes a "majoritarian" default rule based on these data, it would mostly reflect contractual practices preferred by MNEs. It may be assumed that a "majoritarian" default rule could differ if the majority of interviewed organisations were TTOs. Current default rules are primarily addressed at inventors. Thus, these rules may reflect the regime which is more advantageous for natural persons than for legal persons. ${ }^{157}$

The second issue that arises is whether existing contractual practices could even be conveyed into a single "majoritarian" default rule. Even though in this article the contractual practices are clustered into two scenarios, in reality those arrangements are more detailed and differ depending on very complex factual situations and diverging circumstances. It is doubtful that a single rule could be drafted that would reflect all those considerations.

\footnotetext{
156 Ben-Shahar and Pottow, supra n. 15, p. 651.

157 Based on this data set we cannot verify this assumption.
} 
Although the existing default rules cannot be altered to satisfy their secondary function, alternative mechanisms, which could facilitate contract negotiation and decrease contracting costs, should be examined. In particular, the negotiation of $R \& D$ partnerships may be facilitated through the implementation of model agreements and guidelines adopted by, for instance, international or intergovernmental organisations and/or industrial associations. ${ }^{158}$ Those mechanisms are better suited to tailor the provisions to different scenarios that depend on the varying circumstances.

In my view, the Organisation for Economic Co-operation and Development (OECD) ${ }^{159}$ is the best suited intergovernmental organisation to introduce the suggested guidelines and related model agreements. One of the key study subjects of the OECD are innovation, innovation policy, and strategy. ${ }^{160}$ The suggested project fits well into this agenda. Furthermore, OECD publications cover a lot of relevant topics, including OI. ${ }^{161}$ They are also experienced in developing guidelines. ${ }^{162}$

Regional or national industry associations, such as the European Federation of Pharmaceutical Industries Association (EFPIA) ${ }^{163}$ or the Industrial

158 For instance, Lambert decision guidance notes and sample agreements ("University and business collaboration agreements: Lambert Toolkit") which cover university-industry collaborations are well-known and considered to be a useful reference for contract negotiations in university-industry settings (https://www.gov.uk/guidance/university-andbusiness-collaboration-agreements-lambert-toolkit). Those guidance notes and sample agreements provide different options for the allocation of foreground IP and other contractual matters, depending on various considerations. In particular, the representative of C 2 expressed that those sample agreements were "very nice as a guideline, it offered some real balanced interests of all the parties" (C 2, supra $\mathrm{n} .121)$.

159 http://www.oecd.org.

160 http://www.oecd.org/innovation/.

161 E.g. OECD, Open Innovation in Global Networks (OECD 2008).

162 E.g. Oslo Manual, "Guidelines for Collecting, Reporting and Using Data on Innovation" (2018), available at https://read.oecd-ilibrary.org/science-and-technology/oslo-manual2018 9789264304604-en\#page1 (accessed on 26 July 2019).

163 https://www.efpia.eu. 
Minerals Association - Europe (IMA-Europe), ${ }^{164}$ could also introduce the guidelines. In that case, however, the guidelines would not have a unified format and scope and may significantly differ per industry sector or per country/region.

Legislators, however, could potentially tackle the second reason why existing default rules are not favoured by collaborating organisations. In particular, legislators could harmonise the default rules on exploitation of coowned patents. ${ }^{165}$ This initiative could diminish legal uncertainty related to exploitation of co-owned patents in the international context when the primary "gap-filling" function of default rules is to be exercised. Following the expressed preferences of interviewees, default rules on exploitation rights should be more control-based (as, for instance, suggested by Belgian default rules) since collaborating parties are rarely capable of building such a high level of trust in their relationship to be comfortable with allowing the partner to exploit coowned patents without the consent (as suggested by US default rules). However, this measure would only be efficient if the default rules are harmonised on a broad scale, which calls the feasibility of this proposal into question. Nonetheless, harmonising the default rules at least on the EU level could be a valuable first step in increasing the level of legal certainty related to exploitation of co-owned patents in the EU context and with regard to the EU technology markets.

\section{Conclusions}

The allocation of patent ownership of jointly developed inventions is one of the major challenges when negotiating R\&D partnerships. In this article both legislative (default regime) and contractual (contract-based regime) approaches towards the ownership allocation were reviewed. I concluded on the basis of

\footnotetext{
164 https://www.ima-europe.eu.

165 The German legislator should also adopt specialised default rules on patent co-ownership.
} 
extensive empirical research that national default rules are not "sticky" since collaborating parties tend to heavily rely on their right to contract out of them and establish the rules applicable to their relationship. Collaborating parties prefer not to follow the default rules for several reasons. First, differences in national default rules significantly complicate exploitation of co-owned patents and increase coordination costs. Contractual parties are willing to increase costs related to contract negotiations, rather than risk legal uncertainly created by existing default rules. Second, default rules often do not reflect the interests of (one of) the collaborating parties, especially if at least one of the parties is a company. Companies rather prefer to opt for the "sole ownership regime", under which either one of the parties own all R\&D outcomes or each party solely owns patents related to their business interests. The "hybrid regime" - under which collaborating parties co-own R\&D outcomes but contractually specify exploitation rights - is considered to be the second-best scenario for companies.

Furthermore, I argue that the legislator cannot alter existing normative default rules to reflect the preferences of the majority. The specific contractual rules established by collaborating parties are complex, depend on various circumstances and cannot be transmitted into a single default rule. Moreover, the legislator should not legislatively prioritise commercial interests of one type of actor over the principles of fairness and equal treatment. However, the negotiation of R\&D partnerships may be facilitated through implementation of model agreements and guidelines. Those mechanisms are better suited to tailor the provisions to different scenarios that depend on different circumstances. 


\section{Acknowledgments}

The author would like to thank Prof. Dr. Esther van Zimmeren, Prof. Dr. Geertrui Van Overwalle, and Dr. Christopher Heath for reviewing the earlier draft of this paper and for their valuable comments. The author would also like to thank Prof. Dr. Katherine Strandburg for inspiring discussions and suggestions on the topic of the paper. The author thanks Dr. Adrián Kovács, Dr. Dominik Moškvan, and Dr. Amandine Leonard for helpful suggestions and discussions. The author also thanks the anonymous reviewers of this journal for their constructive and valuable comments. The author gratefully acknowledged the financial support of the Research Foundation - Flanders (FWO). 
Annex I: Overview of organisations interviewed ${ }^{166}$

\begin{tabular}{|c|c|c|c|c|c|}
\hline № & NAME & INTERVIEWEE & $\begin{array}{c}\text { INDUSTRY } \\
\text { SECTOR }\end{array}$ & TYPE & $\begin{array}{l}\text { COUNTRY OF } \\
\text { INTERVIEWEE'S } \\
\text { LOCATION }\end{array}$ \\
\hline 1 & $\begin{array}{l}\text { Company } \\
1 \text { (C 1) }\end{array}$ & $\begin{array}{l}\text { Interviewee } 1 \\
\text { Interviewee } 2\end{array}$ & Basic materials & MNE & Belgium \\
\hline 2 & RI 1 & Interviewee 1 & ICT & RI & Belgium \\
\hline 3 & C 2 & Interviewee 1 & Healthcare & MNE & The Netherlands \\
\hline 4 & C 3 & Interviewee 1 & Basic materials & MNE & Belgium \\
\hline 5 & $\mathrm{C} 4$ & $\begin{array}{l}\text { Interviewee } 1 \\
\text { Interviewee } 2\end{array}$ & Healthcare & SME & Belgium \\
\hline 6 & C 5 & Interviewee 1 & Basic materials & MNE & Belgium \\
\hline 7 & C 6 & Interviewee 1 & Healthcare & SME & Belgium \\
\hline 8 & C 7 & Interviewee 1 & Basic materials & MNE & Belgium \\
\hline 9 & C 8 & Interviewee 1 & Basic materials & MNE & Belgium \\
\hline 10 & C 9 & Interviewee 1 & Healthcare & MNE & Belgium \\
\hline 11 & C 10 & Interviewee 1 & Healthcare & SME & Belgium \\
\hline 12 & C 11 & Interviewee 1 & ICT & MNE & Belgium \\
\hline 13 & C 12 & Interviewee 1 & $\mathrm{ICT}$ & MNE & Belgium \\
\hline 14 & C 13 & Interviewee 1 & Healthcare & MNE & Belgium \\
\hline 15 & C 14 & Interviewee 1 & Healthcare & MNE & Belgium \\
\hline 16 & C 15 & $\begin{array}{l}\text { Interviewee } 1 \\
\text { Interviewee } 2\end{array}$ & $\begin{array}{l}\text { Consumer } \\
\text { goods }\end{array}$ & MNE & Belgium \\
\hline 17 & C 16 & Interviewee 1 & Oil \& gas & MNE & Germany \\
\hline 18 & C 17 & Interviewee 1 & Basic materials & MNE & Belgium \\
\hline 19 & TTO 1 & Interviewee 1 & Academia & TTO & Belgium \\
\hline 20 & RI 2 & Interviewee 1 & ICT & RI & Belgium \\
\hline 21 & C 18 & Interviewee 1 & Basic materials & MNE & Belgium \\
\hline
\end{tabular}

166 The overview is chronological (February 2015 - March 2018). 


\begin{tabular}{|c|c|c|c|c|c|}
\hline 22 & TTO 2 & $\begin{array}{l}\text { Interviewee } 1 \\
\text { Interviewee } 2 \\
\text { Interviewee } 3\end{array}$ & Academia & TTO & Belgium \\
\hline 23 & TTO 3 & Interviewee 1 & Academia & TTO & Belgium \\
\hline 24 & TTO 4 & $\begin{array}{l}\text { Interviewee } 1 \\
\text { Interviewee } 2\end{array}$ & Academia & TTO & Belgium \\
\hline 25 & C 19 & Interviewee 1 & Healthcare & MNE & The Netherlands \\
\hline 26 & C 20 & Interviewee 1 & Healthcare & SME & Belgium \\
\hline 27 & C 21 & Interviewee 1 & Oil \& gas & MNE & The United States \\
\hline 28 & C 22 & Interviewee 1 & $\begin{array}{l}\text { Consumer } \\
\text { goods }\end{array}$ & MNE & The Netherlands \\
\hline 29 & C 23 & Interviewee 1 & Healthcare & SME & Belgium \\
\hline 30 & C 24 & $\begin{array}{l}\text { Interviewee } 1 \\
\text { Interviewee } 2\end{array}$ & Basic materials & MNE & The Netherlands \\
\hline 31 & C 25 & Interviewee 1 & $\begin{array}{l}\text { Consumer } \\
\text { goods }\end{array}$ & MNE & The Netherlands \\
\hline 32 & C 26 & Interviewee 1 & Basic materials & MNE & Belgium \\
\hline 33 & C 27 & Interviewee 1 & Healthcare & SME & The Netherlands \\
\hline 34 & RI 3 & Interviewee 1 & Healthcare & RI & Belgium \\
\hline 35 & C 28 & Interviewee 1 & Basic materials & MNE & Belgium \\
\hline 36 & C 29 & Interviewee 1 & Basic materials & MNE & The Netherlands \\
\hline 37 & C 30 & Interviewee 1 & Healthcare & SME & The Netherlands \\
\hline 38 & C 31 & Interviewee 1 & Healthcare & MNE & The Netherlands \\
\hline 39 & C 32 & $\begin{array}{l}\text { Interviewee } 1 \\
\text { Interviewee } 2\end{array}$ & Healthcare & SME & Belgium \\
\hline 40 & C 33 & Interviewee 1 & Basic materials & MNE & The Netherlands \\
\hline 41 & C 34 & $\begin{array}{l}\text { Interviewee } 1 \\
\text { Interviewee } 2\end{array}$ & Healthcare & MNE & Switzerland \\
\hline 42 & C 35 & Interviewee 1 & $\begin{array}{l}\text { Consumer } \\
\text { goods }\end{array}$ & MNE & Belgium \\
\hline 43 & C 36 & $\begin{array}{l}\text { Interviewee } 1 \\
\text { Interviewee } 2\end{array}$ & Healthcare & MNE & Spain \\
\hline
\end{tabular}




\begin{tabular}{|c|c|c|c|c|c|}
\hline & & Interviewee 3 & & & \\
\hline 44 & TTO 5 & Interviewee 1 & Academia & TTO & The United States \\
\hline 45 & C 37 & Interviewee 1 & ICT & MNE & The United States \\
\hline 46 & TTO 6 & Interviewee 1 & Academia & TTO & The United States \\
\hline 47 & TTO 7 & Interviewee 1 & Academia & TTO & The United States \\
\hline 48 & TTO 8 & $\begin{array}{l}\text { Interviewee } 1 \\
\text { Interviewee } 2\end{array}$ & Academia & TTO & The United States \\
\hline 49 & C 38 & Interviewee 1 & ICT & MNE & The United States \\
\hline 50 & TTO 9 & Interviewee 1 & Academia & TTO & The United States \\
\hline 51 & TTO 10 & Interviewee 1 & Academia & TTO & The United States \\
\hline 52 & C 39 & Interviewee 1 & Basic materials & MNE & The United States \\
\hline 53 & TTO 11 & Interviewee 1 & Academia & TTO & The United States \\
\hline 54 & TTO 12 & Interviewee 1 & Academia & TTO & The United States \\
\hline 55 & TTO 13 & Interviewee 1 & Academia & TTO & The United States \\
\hline 56 & C 40 & Interviewee 1 & Healthcare & MNE & Belgium \\
\hline
\end{tabular}




\section{Annex II: Contractual practices to allocate ownership of jointly developed inventions and related exploitation} rights $^{167}$

\begin{tabular}{|c|c|c|c|c|}
\hline № & Organisation & $\begin{array}{c}\text { Scenario } 1 \\
\text { "Default regime" }\end{array}$ & $\begin{array}{c}\text { Scenario } 2 \\
\text { "Hybrid regime" }\end{array}$ & $\begin{array}{c}\text { Scenario } 3 \\
\text { "Sole ownership } \\
\text { regime" }\end{array}$ \\
\hline 1 & C 1 & $x$ & $\checkmark[2]$ & $\checkmark[1]$ \\
\hline 2 & $\mathrm{C} 2$ & $x$ & $\checkmark[2]$ & $\checkmark[1]$ \\
\hline 3 & C 3 & $x$ & $\checkmark[2]$ & $\checkmark[1]$ \\
\hline 4 & C 4 & $x$ & $\checkmark[2]$ & $\checkmark[1]$ \\
\hline 5 & C 5 & $x$ & $\checkmark[2]$ & $\checkmark[1]$ \\
\hline 6 & C 6 & $x$ & $\checkmark[2]$ & $\checkmark[1]$ \\
\hline 7 & C 7 & $x$ & $x$ & $\checkmark[1]$ \\
\hline 8 & C 8 & $x$ & $x$ & $\checkmark[1]$ \\
\hline 9 & C 9 & $x$ & $\checkmark[2]$ & $\checkmark[1]$ \\
\hline 10 & C 10 & $x$ & $\checkmark[2]$ & $\checkmark[1]$ \\
\hline 11 & C 11 & $x$ & $x$ & $\checkmark[1]$ \\
\hline 12 & C 12 & $x$ & $\checkmark[2]$ & $\checkmark[1]$ \\
\hline 13 & C 13 & $x$ & $\checkmark[2]$ & $\checkmark[1]$ \\
\hline 14 & C 14 & $x$ & $\checkmark[2]$ & $\checkmark[1]$ \\
\hline 15 & C 15 & $x$ & $x$ & $\checkmark[1]$ \\
\hline 16 & C 16 & $x$ & $x$ & $\checkmark[1]$ \\
\hline 17 & C 17 & $x$ & $x$ & $\checkmark[1]$ \\
\hline 18 & C 18 & $x$ & $\checkmark[2]$ & $\checkmark[1]$ \\
\hline 19 & C 19 & $x$ & $\checkmark[2]$ & $\checkmark[1]$ \\
\hline 20 & C 20 & $x$ & $x$ & $\checkmark[1]$ \\
\hline
\end{tabular}

$167 \times$ means that the scenario is not applied; $\checkmark$ means that the scenario is applied; [1] indicates that the scenario is preferred; [2] suggests that it is the second-best scenario. If there is no clear preference, [1] is placed for both scenarios. 


\begin{tabular}{|c|c|c|c|c|}
\hline 21 & C 21 & $x$ & $x$ & $\checkmark[1]$ \\
\hline 22 & C 22 & $x$ & $x$ & $\checkmark[1]$ \\
\hline 23 & C 23 & $x$ & $\checkmark[1]$ & $\checkmark[1]$ \\
\hline 24 & C 24 & $x$ & $\checkmark[2]$ & $\checkmark[1]$ \\
\hline 25 & C 25 & $x$ & $\checkmark[2]$ & $\checkmark[1]$ \\
\hline 26 & C 26 & $x$ & $\checkmark[2]$ & $\checkmark[1]$ \\
\hline 27 & C 27 & $x$ & $\checkmark[2]$ & $\checkmark[1]$ \\
\hline 28 & C 28 & $x$ & $x$ & $\checkmark[1]$ \\
\hline 29 & C 29 & $x$ & $\checkmark[2]$ & $\checkmark[1]$ \\
\hline 30 & C 30 & $x$ & $\checkmark[1]$ & $\checkmark[1]$ \\
\hline 31 & C 31 & $x$ & $x$ & $\checkmark[1]$ \\
\hline 32 & C 32 & $x$ & $x$ & $\checkmark[1]$ \\
\hline 33 & C 33 & $x$ & $\checkmark[2]$ & $\checkmark[1]$ \\
\hline 34 & C 34 & $x$ & $\checkmark[2]$ & $\checkmark[1]$ \\
\hline 35 & C 35 & $x$ & $x$ & $\checkmark[1]$ \\
\hline 36 & C 36 & $x$ & $x$ & $\checkmark[1]$ \\
\hline 37 & C 37 & $x$ & $x$ & $\checkmark[1]$ \\
\hline 38 & C 38 & $x$ & $\checkmark[2]$ & $\checkmark[1]$ \\
\hline 39 & C 39 & $x$ & $\checkmark[2]$ & $\checkmark[1]$ \\
\hline 40 & C 40 & $x$ & $\checkmark[2]$ & $\checkmark[1]$ \\
\hline 41 & TTO 1 & $x$ & $\checkmark[1]$ & $\checkmark[1]$ \\
\hline 42 & TTO 2 & $x$ & $\checkmark[1]$ & $\checkmark[1]$ \\
\hline 43 & TTO 3 & $x$ & $\checkmark[1]$ & $\checkmark[1]$ \\
\hline 44 & TTO 4 & $x$ & $\checkmark[1]$ & $\checkmark[1]$ \\
\hline 45 & TTO $5^{168}$ & $x$ & $\checkmark[1]$ & $\checkmark[1]$ \\
\hline 46 & TTO 6 & $x$ & $\checkmark[1]$ & $\checkmark[1]$ \\
\hline
\end{tabular}

168 It must be stressed that TTOs 5-13 are US TTOs. US TTOs insist on allocating the ownership of developed inventions based on inventorship. 


\begin{tabular}{|c|c|c|c|c|}
\hline 47 & TTO 7 & $x$ & $\checkmark[1]$ & $\checkmark[1]$ \\
\hline 48 & TTO 8 & $x$ & $\checkmark[1]$ & $\checkmark[1]$ \\
\hline 49 & TTO 9 & $x$ & $\checkmark[1]$ & $\checkmark[1]$ \\
\hline 50 & TTO 10 & $x$ & $\checkmark[1]$ & $\checkmark[1]$ \\
\hline 51 & TTO 11 & $x$ & $\checkmark[1]$ & $\checkmark[1]$ \\
\hline 52 & TTO 12 & $x$ & $\checkmark[1]$ & $\checkmark[1]$ \\
\hline 53 & TTO 13 & $x$ & $\checkmark[1]$ & $\checkmark[1]$ \\
\hline 54 & RI 1 & $x$ & $\checkmark[1]$ & $\checkmark[1]$ \\
\hline 55 & RI 2 & $x$ & $\checkmark[1]$ & $\checkmark[1]$ \\
\hline 56 & RI 3 & $x$ & $\checkmark[1]$ & $\checkmark[1]$ \\
\hline
\end{tabular}

